\title{
Transcriptome analysis of neural progenitor cells derived from Lowe syndrome induced pluripotent stem cells: identification of candidate genes for the neurodevelopmental and eye manifestations
}

Hequn Liu ${ }^{1 \dagger}$, Jesse Barnes ${ }^{1 \dagger}$, Erika Pedrosa ${ }^{2}$, Nathaniel S. Herman ${ }^{2}$, Franklin Salas ${ }^{2}$, Ping Wang ${ }^{1}$, Deyou Zheng ${ }^{1,3,4^{*}+}$ and Herbert M. Lachman ${ }^{1,2,3,5^{*}}$

\begin{abstract}
Background: Lowe syndrome (LS) is caused by loss-of-function mutations in the X-linked gene OCRL, which codes for an inositol polyphosphate 5-phosphatase that plays a key role in endosome recycling, clathrin-coated pit formation, and actin polymerization. It is characterized by congenital cataracts, intellectual and developmental disability, and renal proximal tubular dysfunction. Patients are also at high risk for developing glaucoma and seizures. We recently developed induced pluripotent stem cell (iPSC) lines from three patients with LS who have hypomorphic variants affecting the $3^{\prime}$ end of the gene, and their neurotypical brothers to serve as controls.
\end{abstract}

Methods: In this study, we used RNA sequencing (RNA-seq) to obtain transcriptome profiles in LS and control neural progenitor cells (NPCs).

Results: In a comparison of the patient and control NPCs $(n=3)$, we found 16 differentially expressed genes (DEGs) at the multiple test adjusted $p$ value (padj) $<0.1$, with nine at padj $<0.05$. Using nominal $p$ value $<0.05,319$ DEGs were detected. The relatively small number of DEGs could be due to the fact that OCRL is not a transcription factor per se, although it could have secondary effects on gene expression through several different mechanisms. Although the number of DEGs passing multiple test correction was small, those that were found are quite consistent with some of the known molecular effects of OCRL protein, and the clinical manifestations of LS. Furthermore, using gene set enrichment analysis (GSEA), we found that genes increased expression in the patient NPCs showed enrichments of several gene ontology $(G O)$ terms (false discovery rate $<0.25$ ): telencephalon (Continued on next page)

\footnotetext{
* Correspondence: deyou.zheng@einstein.yu.edu;

herb.lachman@einstein.yu.edu

Hequn Liu, Jesse Barnes, Deyou Zheng are shared equally..

'Department of Genetics, Albert Einstein College of Medicine, Bronx, New York, USA

Full list of author information is available at the end of the article
}

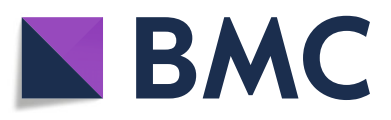

(- The Author(s). 2020 Open Access This article is licensed under a Creative Commons Attribution 4.0 International License, which permits use, sharing, adaptation, distribution and reproduction in any medium or format, as long as you give appropriate credit to the original author(s) and the source, provide a link to the Creative Commons licence, and indicate if changes were made. The images or other third party material in this article are included in the article's Creative Commons licence, unless indicated otherwise in a credit line to the material. If material is not included in the article's Creative Commons licence and your intended use is not permitted by statutory regulation or exceeds the permitted use, you will need to obtain permission directly from the copyright holder. To view a copy of this licence, visit http://creativecommons.org/licenses/by/4.0/. The Creative Commons Public Domain Dedication waiver (http://creativecommons.org/publicdomain/zero/1.0/) applies to the data made available in this article, unless otherwise stated in a credit line to the data. 


\begin{abstract}
(Continued from previous page)
development, pallium development, NPC proliferation, and cortex development, which are consistent with a condition characterized by intellectual disabilities and psychiatric manifestations. In addition, a significant enrichment among the nominal DEGs for genes implicated in autism spectrum disorder (ASD) was found (e.g., AFF2, DNER, DPP6, DPP10, RELN, CACNA1C), as well as several that are strong candidate genes for the development of eye problems found in LS, including glaucoma. The most notable example is EFEMP1, a well-known candidate gene for glaucoma and other eye pathologies.

Conclusion: Overall, the RNA-seq findings present several candidate genes that could help explain the underlying basis for the neurodevelopmental and eye problems seen in boys with LS.
\end{abstract}

Keywords: Lowe syndrome, Dent disease, EFEMP1, Glaucoma, Macular degeneration, Cataracts, OCRL, MEIS2, TMEM132, SPON1, DPP10, Kv4.2

\section{Introduction}

Lowe syndrome (LS) (OMIM \#300535) is a rare genetic disorder $(\sim 1 / 500,000$ males $)$ caused by mutations in the X-linked gene, OCRL $(O C R L-1)[1-4]$. It is characterized by the triad of congenital cataracts, intellectual and developmental disability (IDD), and renal proximal tubular dysfunction [1, 5-10]. Hypotonia, epilepsy, stereotypical behaviors, and a high rate of glaucoma are also observed.

OCRL codes for a 901 amino acid protein, inositol polyphosphate 5-phosphatase that plays a key role in endosome trafficking, clathrin-coated pit formation, and actin polymerization, by catalyzing the removal of the $5^{\prime}$ phosphate from phosphatidylinositol 4,5bisphosphate (PI(4,5)P2), phosphatidylinositol 1,4,5trisphosphate, and inositol 1,3,4,5-tetrakisphosphate [10-16].

The molecular basis of LS has primarily been studied in fibroblasts derived from patients and immortalized cell lines (e.g., HeLa; Cos-7 cells). These studies show that abnormalities in endosome recycling, in particular, megalin receptor recycling in the proximal tubules, and primary cilia dysfunction in the eye, underlie some of the clinical features [7, 11, 17-21]. However, the neurodevelopmental and behavioral aspects of LS have not been adequately investigated in human neuronal cells or animal models. A zebrafish ocrl1 deficiency model has been developed, in which an increase in the susceptibility to heat-induced seizures, cystic brain lesions, and reduced Akt signaling have been observed [22]. Unfortunately, Ocrl knockout $(\mathrm{KO})$ mice have significant limitations as a model system to study the neurodevelopmental aspect of LS. The original KO mouse is asymptomatic, due to compensation by the Ocrl paralog, Inpp $5 b$, since a double Ocrl/Inpp5b KO is embryonic lethal [23-25]. Recently, a mouse model was developed by expressing the human INPP5B gene, which rescues the double $\mathrm{KO}$, embryonic lethal phenotype KO [26]. These mice show an endolysosomal deficit in cultured proximal tubule cells. However, learning and behavioral deficits and eye pathologies were not observed.

Because of the dearth of neurodevelopmental findings in $\mathrm{Ocrl} \mathrm{KO}$ mice, we developed an induced pluripotent stem cell (iPSC) model from three patients and their typically developing brothers. All three LS subjects have hypomorphic mutations affecting the Cterminal end of the protein [27]. We previously showed that neural progenitor cells (NPCs) derived from patient-specific iPSCs are deficient in their capacity to produce filamentous actin fibers (F-actin) and WAVE-1, a component of the WAVE regulatory complex (WRC) that controls actin polymerization [27]. The effect of these deficits on neuronal function is currently under investigation.

Although our preliminary studies have focused on some of the known effects of OCRL described in non-neuronal cells, we are also interested in identifying molecular and cellular pathways that might be uniquely affected in neural cells. One effective approach to examine molecular disruptions in an unbiased, genome-wide manner is RNA-seq. Our previous RNA-seq studies have resulted in the discoveries of novel pathways involved in CHD8-associated autism spectrum disorder (ASD), schizophrenia (SZ) associated with 22q11.2 deletion syndrome, and a mouse model for Rett syndrome [28-30]. RNA-seq has also been used successfully by other groups to identify pathways of interest in neuropsychiatric and neurodevelopmental disorders [31-35].

Consequently, RNA-seq was used to screen NPCs derived from LS-specific iPSCs and controls; their typically developing brothers. At the significant level of nominal $p$ value $<0.05,319$ differentially expressed genes (DEGs) were found. Among them, 16 remained statistically significant after multiple test correction at the adjusted $p$ (padj) $<0.1$, and nine at the padj $<0.05$. However, among these, there were several strong candidates for the eye and behavioral/ neurological pathologies seen in LS; most notably, EFEMP1, DPP10, and SPON1. 


\section{Methods}

\section{Subjects}

The study and consent forms were approved by the Albert Einstein College of Medicine (AECOM) internal review board (IRB). A diagnosis of LS was made during infancy in each patient based on clinical findings (congenital cataracts, hypotonia), fibroblast OCRL enzyme activity, and ultimately by genotyping. The patients (LS100, LS300, LS500) harbor mutations in the 3 ' end of the gene that codes for the ASH-RhoGap domain (Table 1). A detailed molecular genetic analysis of the effects of these mutations on splicing can be found in our previous publication [27]. Their neurotypically developing brothers (LS200, LS400, and LS600, respectively) served as controls. All subjects were between 11 and 25 years of age when recruited, and the sibling pairs were $2-4$ years apart in age.

\section{Development of iPSCs cells from peripheral blood CD34 ${ }^{+}$cells} iPSC lines were generated from human peripheral blood $\mathrm{CD}_{4}{ }^{+}$cells with a CytoTune-iPS 2.0 Sendai Reprogramming Kit (Invitrogen) as previously described [36]. The growth and maintenance of the iPSCs used in this study are described in our recent publication [27].

\section{Generating neural progenitor cells from iPSCs using dual SMAD inhibition}

A monolayer neural progenitor cell (NPC) culture protocol was adapted from the STEMCELL Technologies STEMdiff $^{T M}$ SMADi Neural Induction Kit with slight modifications. Briefly, iPSCs were maintained in mTeSR1 with daily feeding until cells reached the point of passaging. At the start of induction, differentiated cells, if present, were manually removed and the iPSCs were washed with PBS. Gentle dissociation reagent (STEMCELL Tech) was added for 8-10 min at $37{ }^{\circ} \mathrm{C}$. Cells were dislodged by pipetting with a sterile $1 \mathrm{ml}$ pipet tip and collected in a $15 \mathrm{ml}$ tube. Cell culture plates were rinsed with DMEM/F12 and added to the tube containing the cell suspension. Viable cells were counted with a hemocytometer using the Trypan Blue exclusion method. Cells were then centrifuged at $300 \times g$ for $5 \mathrm{~min}$. Supernatant was carefully aspirated and the cell pellet was re-suspended in STEMdiff ${ }^{T M}$ SMADi Neural Induction Medium $+10 \mu \mathrm{M}$ Y-27632 to obtain a final concentration of $10^{6} \mathrm{cell} / \mathrm{ml}$. Two milliliters of cell suspension were aliquoted to one well of a 6-well plate that was pre-coated with matrigel. This was designated as passage 0 (P0). Cells were allowed to grow with daily feeding for 6 days in STEMdiff
SMADi Neural Induction medium. Note that Y-27632 is not required for the daily medium changes. NPCs were ready for passage when cultures were approximately $90 \%$ confluent (6 days). For passaging, NPCs were washed with DMEM/F12 and $1 \mathrm{ml}$ of accutase was added to each well for $5 \mathrm{~min}$ at $37^{\circ} \mathrm{C}$. Cells were dislodged with a sterile $1 \mathrm{ml}$ pipet tip and collected in a $15 \mathrm{ml}$ tube containing DMEM/ F12. Viable cells were counted using Trypan Blue exclusion. Cells were then centrifuged at $300 \times g$ for $5 \mathrm{~min}$. Supernatant was carefully aspirated and the cell pellet was re-suspended in STEMdiff ${ }^{\mathrm{TM}}$ SMADi Neural Induction Medium $+10 \mu \mathrm{M}$ Y-27632. Cells were plated at a density of $1.5 \times 10^{6}$ live cells/well in a 6-well plate pre-coated with PORN/Laminin. NPCs were fed daily, without Y-27632m, and were ready for downstream applications at passage 3 . At this stage, none of the cells stained for the stem cell marker, OCT4 (POU5F1) and virtually $100 \%$ were positive for the NPC markers vimentin and SOX2 (Additional file 1: Figure S1). Furthermore, we compared our NPC RNA-seq data with gene expression in multiple neural and non-neural cell lines (or tissues) analyzed by RNA-seq in the ENCODE project [37] and found that the most correlated cell line was neural progenitor cell (ENCFF663ARH, Pearson's correlation coefficients $(r)=0.88$ ) (Additional file 2: Figure S2).

\section{RNA-seq}

Total cellular RNA was extracted using the miRNeasy Mini Kit (QIAGEN, catalogue\# 217004) according to the manufacturer's instructions (QIAGEN). An additional treatment with DNase I (QIAGEN, Valencia, CA) was included to remove genomic DNA. After passing quality control, high throughput sequencing libraries were prepared by Novogene, and 150 bp paired-end RNA-seq reads were obtained. RNA-seq reads were aligned to the human reference genome (hg19) by the software HISAT2 (v2.0.4) [38]. HTseq (v0.11.0) [39] was used to determine the read counts while the StringTie (v1.2.2) [40] was used to compute fragments per kilobase of exon per million fragments mapped (FPKM) and transcript per million (TPM) for each of the genes annotated in the GENCODE database (v29) [41], including protein-coding, non-coding, and all other transcript types. Genes with TPM $>1$ in at least one of the 12 samples were used for downstream analysis. RNA-seq read counts of the two biological replicates (A/B) were merged using the "collapseReplicates" function in the software DESeq2 [42], resulting in three samples each for the patient and control NPCs for differential expression analysis genes by DESeq2.

Table 1 OCRL mutations in patients

\begin{tabular}{lllll}
\hline Patient & Exon/intron & Mutation & Genomic position (hg19) & Type \\
\hline LS100 & Intron 23 & c.2582-1 G>T & chrX:128724122 & Splice acceptor \\
LS300 & Intron 22 & c.2470-2 A>G & chrX:128723820 & Splice acceptor \\
LS500 & Exon 20 & c.2179delC & chrX:128721069 & Del/frame shift \\
\hline
\end{tabular}


The overlap of DEGs with various disease gene lists was evaluated for statistical significance by Fisher's test. We also performed gene set enrichment analysis (GSEA; v4.0.1), using the gene sets in the gene ontology (GO) "Biological Process" category and ranking genes $(n=20,728)$ by fold changes ("log2_Ratio_of_Classes"), and otherwise default parameters.

\section{Quantitative real time PCR}

Quantitative real-time PCR (qPCR) was carried out on reverse-transcribed PCR using the $2^{-\Delta \Delta \mathrm{Ct}}$ method as we previously described $[28,29,43]$.

\section{Immunocytochemistry}

Immunocytochemistry (ICC) was carried out as previously described [27] using mouse anti-Vimentin (Invitrogen cat\#18-0052) at a 1:100 dilution, and Anti-Sox2 (StemCell Technologies cat\#60055.1) at a 1:50 dilution.

\section{Western blotting}

Proteins were prepared with ProteoExtract Complete Mammalian Proteome Extraction Kit (Millipore cat\# 539779) according to the manufacturer's protocol. Protein concentrations were verified using the Bradford method. Briefly, 30-60 $\mu \mathrm{g}$ of protein were denatured with the addition of Laemmli buffer and 2-mercaptoethanol, and boiled for $5 \mathrm{~min}$. Samples were loaded onto a 12\% precast polyacrylamide gel (BIO-RAD cat\#456-1044). Gel electrophoresis was set at constant voltage $(50 \mathrm{~V})$ for the first 30 min and $120 \mathrm{~V}$ for the remainder of the run. The running buffer was in $1 \times$ TrisGlycine/SDS buffer. After separation by electrophoresis, proteins were transferred using the TransBlot ${ }^{\circ}$ TurboTM Transfer System according to the manufacturer's instructions. A 7-min transfer was executed using the turbo program setting. After transfer, membranes were blocked in 5\% milk with gentle agitation for $1 \mathrm{~h}$ at room temperature. Membranes were then incubated overnight with gentle agitation at $4{ }^{\circ} \mathrm{C}$ with primary antibodies for 48 h (Anti-OCRL; Proteintech Group, catalog\# 17695-1-AP, 1 : 500 dilution: Anti-GAPDH; ThermoFisher Scientific, catalog\# MA5-15738, 1:2,000 dilution). Following primary antibody incubation, membranes were washed three times with gentle agitation in $1 \times \mathrm{TBS} / \mathrm{T}$ buffer $(20 \mathrm{mM}$ Tris Base, $0.136 \mathrm{M} \mathrm{NaCl}, 0.1 \%$ Tween-20). Membranes were then incubated with a secondary antibody (1:5,000 dilution) plus anti-biotin (1:2,000 dilution) for $1 \mathrm{~h}$ at room temperature with gentle agitation. Membranes were washed again, as above, and subsequently incubated with SuperSignal ${ }^{\mathrm{TM}}$ West Dura Extended Duration Substrate (Thermo Scientific cat\# 34075) for $5 \mathrm{~min}$ at room temperature with gentle agitation. Immediately thereafter, membranes were exposed to blue autoradiograph film for visualization. For quantification, autoradiograms were scanned and the protein of interest was normalized against a control protein, GAPDH

\section{OCRL knockdown}

An immortalized human retinal pigmented epithelium cell line, RPE-1 (ATCC ${ }^{\bullet}$ Number: CRL-4000), was used for OCRL knockdown (KD) experiments. These were carried out with Dharmacon ${ }^{\text {TM }}$ siGENOME Human OCRL siRNA (cat\# D-010026-01-0005, Horizon Discovery) and were transfected into RPE cells using DharmaFECT 1 Transfection reagent (Horizon Discovery) in DMEM medium containing 10\% FBS without antibiotics. siGENOME nontargeting siRNA \#3 (cat\#D-001210-03-05, Horizon Discovery) was used as a control. siRNAs were transfected into RPE-1 cells at a concentration of $25 \mathrm{nM}$ for $72 \mathrm{~h}$ according to the manufacturer's protocol.

\section{PCR primers used in this study}

\begin{tabular}{lll}
\hline Gene & Left & Right \\
B2M & gctcgcgctactctctcttt & caatgtcggatggatgaaac \\
OCRL_LS500 & cctgcatgaccagaatttga & ttaaaagcgctatgctgacg \\
OCRLexp-F & acaggtcctgcttcccacta & tggaggtggatgtctaggca \\
OCRLexp2-F & atccacctccagagcaacac & gctgtgggaaggagcaatag \\
OCRL_KO & agagctgccctcatttcctt & tgggcctggacttgataaaa \\
LS100cDNA & tttcttggaagccctgcca & tgccataaggttgggtggag \\
LS300CDNA & agcgtcaatgccaacatgatc & aaggagggattaggaaacgctc \\
OCRL_LS100/300 & attgtgttggccatgaggag & ggaggcctcaggagaagact \\
\hline
\end{tabular}

\section{Sequencing primers}

\begin{tabular}{ll}
\hline LS100seq & aatactcttagtgcattgtatc \\
LS300seq & tagaagttagacagatgaaatg \\
LS500 & cctgcatgaccagaatttga \\
\hline
\end{tabular}

qPCR primers

\begin{tabular}{lll}
\hline TMEM132C & cacctctatggcagctctcc & cccgactgttcttcaccact \\
TMEM132D & gaatcctgccagaaatccaa & gtgttggggttagcatcgtt \\
INPP5F & tagcgttcatgctccttcag & atatgtgtacgtcgccagca \\
MEIS2 & ccaggggactacgtttctca & tgagtagggtgtggggtcat \\
SLC1A3a & gccttgagcaagtcccatct & caggatgtctgggctggaag \\
ADCY2 & gtgcgtgctgtctgtcctat & acgatctgggcacacatcag \\
TMEM47 & tcctttgcgctgacaaggat & tcaagggctcactcaagcaa \\
EFEMP1 & aagtgcaatgcttgtgctcg & gcggaaggtccctatactgc \\
RPLPO & ccaccacagctgctcctg & ggctaagttggttgcttttgg \\
DPP10 & gtgtttcgctgcacctatga & agggagggaacaacacacac \\
SPON1 & aggagtagtgtcagccacct & atggttgcctctccatgtgg \\
NLRP2 & atgctagactgggcagagga & cagtccctgaagaccagctc
\end{tabular}


Methods (Continued)

CALB1 tatccaggatgtgtggctca tgggtgtactgactggccta

\section{Results}

RNA-seq and bioinformatics

iPSCs from three subjects with LS and controls were differentiated into NPCs. RNA was extracted and analyzed by paired-end RNA-seq. Two independent NPC samples differentiated from each iPSC line were prepared for duplicated RNA libraries sent for RNA-seq, resulting in a total of 12 biological samples. The overall quality of the RNA-seq reads and alignment was excellent, with a range of 22,150,351-29,297,502 reads, and alignment rates from 85.58 to $90.67 \%$ (Additional file 3: Table S1). In addition, we were able to confirm the mutant OCRL genotype for each patient sample in the RNA-seq reads: loss of intron 23/exon 24 splice site with cryptic splice site in exon 24 (LS100); loss of intron 22/ exon 23 splice site with absence of exon 23 in the final transcript (LS300); and a "C" del in exon 20 (LS500) (Table 1; Additional file 4: Figure S3A-C).

Since the gene expression profiles of the two duplicated samples were highly correlated, we merged them for determining DEGs in NPCs comparing LS samples and their sibling controls $(n=3)$ using the software DESeq2 [42]. At a nominally significant level $(p<0.05), 319$ DEGs were found (164 genes expressed at higher levels in LS; 155 lower) (Additional file 5: Table S2). At the multiple test adjusted $p$ value (padj) $<0.05$, we found nine DEGs (PCDHB5, BARHL1, NLRP2, EFEMP1, SPON1, GDA, CALB1, ZNF736, PITX2), with an additional seven at padj between 0.05 and 0.1 (INPP5F, PEG3, SPINK5, DPP10, $M A F B, O T P, T M E M 132 C$ ) (Fig 1a). Of the 16 DEGs that achieved padj $<0.1$, five are known SZ, ASD, IDD or eye disorder candidate genes (DPP10, GDA, PITX2, EFEMP1, SPON1) (Table 2).

To address the potential limitation in using thresholds for selecting DEGs, we also applied the software GSEA to find enriched GO terms [44, 45]. For genes expressed higher in patient NPCs, 32 "Biological Process"-related GO terms were enriched at false discovery rate (FDR) < 25\% (Fig. 1b). The top GO terms for LS upregulated genes were telencephalon development, pallium development, NPC proliferation, and cortex development, which are consistent with a condition characterized by intellectual disabilities and psychiatric manifestations. For genes showing decreased expression in LS NPCs (an increase in controls), no GO terms passed the 25\% FDR threshold. At a nominal $p$ value $<0.01$, the top terms were vasculature development, nuclear-transcribed mRNA catabolic process, and protein kinase B signaling (Additional file 6: Figure S4).
Finally, we analyzed the overlap of the 319 nominal DEGs with lists of genes that were associated with ASD, schizophrenia (SZ), IDD, and eye diseases in previous studies [46-53] (SFARI [https://gene.sfari.org/autdb/GS Home.do]; https://neibank.nei.nih.gov/cgi-bin/ eyeDiseaseGenes.cgi) (Additional file 7: Table S3). We found that ASD-related genes showed a significant overlap with our DEGs (Fig. 2). Among the more interesting DEGs in the context of behavioral and cognitive problems are AFF2, ADCY2, DNER, DPP10, CACNA1C, $M E I S 2, G D A, R E L N$, which have been linked to neurodevelopmental disorders and neuropsychiatric disorders in multiple studies (Table 2) [54-81]. There was also overlap for genes involved in intellectual disabilities, including AFF2, AIFM1, CA8, EEF1A2, MLC1, and XYLT1 [82-87], but statistically the overlap is not significant.

Interestingly, some enrichment $(\mathrm{OR}=1.45$; Fig. 2$)$ was also seen for DEGs involved in eye disorders, consistent with the clinical problems seen in LS. One such gene is EFEMP1 (EGF containing fibulin extracellular matrix protein 1 ), which was the most significantly upregulated DEG in our study. EFEMP1 has been implicated in glaucoma in several genome-wide association studies (GWAS), macular degeneration, age-related macular dystrophy, and Doyne honeycomb retinal dystrophy [88-94]. EFEMP1 has also been found to be associated with suicidal behavior in genetic and molecular studies [95-98].

Two other DEGs that are involved in both neurodevelopmental and eye pathologies are MEIS2 and SPON1. MEIS2 codes for a homeobox protein, and is a key regulator of trabecular meshwork, lens, and retina development [99-102]. It was also identified as a risk factor in an open-angle glaucoma GWAS [103], and MEIS2 missense mutations and microdeletions have been found in patients with ASD and developmental delay [60-62, 81, 104].

SPON1 codes for SPONDIN-1, an extracellular matrix component involved in axon guidance. Mutations have been found in a SZ exome sequencing study, and genome-wide association studies have implicated the gene in the rate of cognitive decline and dementia severity in Alzheimer disease [105-108]. It is also a differentially expressed protein in the development of cataracts, and is a major target of the Pax6 pathway during lens development [109].

We validated six DEGs by qPCR that were significant at padj <0.1 (EFEMP1, TMEM132C, INPP5F, DPP10, $S P O N 1, C A L B 1)$, as well as six others that were nominally significant $(p<0.05)$, which showed significant differences that were in agreement with the RNA-seq data, with the exception of CALB1. This showed the expected decrease, but only a trend toward statistical significance was found $(p<0.08)$ (Fig. 3). The analysis was carried out on the two 


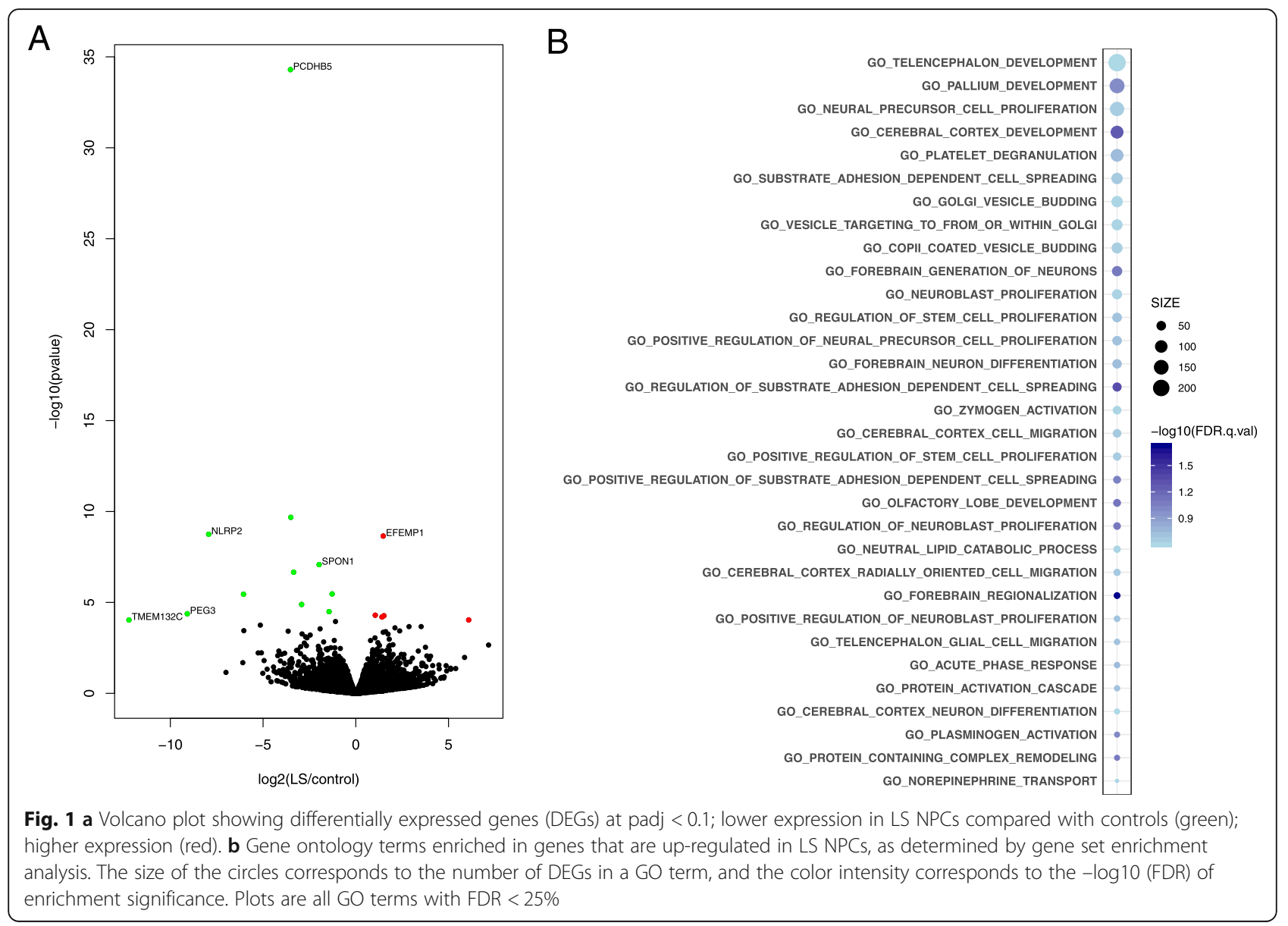

original RNA samples sent for sequencing and an independent set of NPCs.

These findings suggest that the neurodevelopmental features and eye pathologies seen in LS are mediated, in part, by altered expression of the DEGs we identified.

\section{OCRL KD in RPE-1 cells}

To further validate the connection between OCRL expression and genes involved in eye pathology, we knocked down OCRL expression in a human retinal pigmented epithelial cell line, RPE-1. An R345W mutation in EFEMP1 causes Doyne honeycomb retinal dystrophy [92], which leads to activation of the alternative complement pathway in RPE cells [110]. RPE-1 cells were transfected with siRNAs targeting OCRL mRNA, and a scrambled control. As seen in Fig. 4, significant decrease in OCRL protein (left panel), and OCRL mRNA (right panel) occurred in cells treated with OCRL siRNA compared with cells treated with the scrambled control siRNA ( $83 \%$ decrease in normalized OCRL protein, $p=0.02 ; 70 \%$ decrease in normalized OCRL mRNA, $p=3.1 \mathrm{E}-07$, Student's $t$ test, two-tailed). This was accompanied by extremely large increases in the expression of MEIS2, which is a regulator of retinal development, as noted above, and
EFEMP1 mRNA ( $p=0.04$ and 0.03 , respectively, Student's $t$ test, two-tailed). The relatively modest levels of statistical significance compared with large fold changes are due to the small sample size (two independent KD experiments; qPCR carried out in duplicate).

These findings show that the increase in expression of these genes seen in LS NPCs is directly related to the loss of function, patient-specific $O C R L$ mutations found in our subjects.

\section{Discussion}

Overall, the transcriptome findings were relatively modest with respect to the number of DEGs found in all three LS/ control pairs compared to differences found between patients and controls in other iPSC disease-model systems that we have analyzed. For example, transcriptome analyses on NPCs, monolayer neurons, and cerebral organoids derived from CHD8 haploinsufficient iPSC lines resulted in hundreds of shared DEGs with highly significant enrichment of pathways relevant to ASD pathogenesis $[28,30]$. This could reflect the biological function of the underlying candidate genes. CHD8 codes for a member of the CHD family of ATP-dependent chromatinremodeling factors, so major changes in gene expression 
Table 2 Genes involved in ASD, SZ, ID, and eye disorders that overlap with the 319 nominal DEGs. Two additional genes were included based on literature support: MEIS1 is a glaucoma candidate that is not in the NEI/NIH eye database, and SPON1 is not in any of the SZ candidate gene databases, but was recently identified in an exome sequencing study (both denoted by asterisk *). Genes shown in bold type are the DEGs at padj $<0.1$

\begin{tabular}{|c|c|c|c|}
\hline$\overline{A S D}$ & $S Z$ & IDD & EYE \\
\hline AFF2 & BMP6 & AFF2 & CNGB1 \\
\hline ANO5 & CA8 & CA8 & COL2A1 \\
\hline CAB & CACNAIC & EEF1A2 & EFEMP1 \\
\hline CACNAIC & CHN2 & MLC1 & MEIS2* \\
\hline CADPS2 & CHRFAMTA & RELN & PITX2 \\
\hline COMT & COMT & $\mathrm{TH}$ & SPON1* \\
\hline DNAH3 & $M L C 1$ & $X Y L T 1$ & TNFRSF11B \\
\hline DNER & PCDHA6 & & \\
\hline DPP10 & PNPO & & \\
\hline DPP6 & PPP1R16B & & \\
\hline EEF1A2 & PROZ & & \\
\hline GABRG3 & RELN & & \\
\hline GALNTIO & SLCIAB & & \\
\hline$G D A$ & SNCG & & \\
\hline KCND3 & SPON1* & & \\
\hline KCNJ12 & $\mathrm{TH}$ & & \\
\hline MEIS2 & $A D C Y 2$ & & \\
\hline \multicolumn{4}{|l|}{ OTX1 } \\
\hline \multicolumn{4}{|l|}{ PCDHA6 } \\
\hline \multicolumn{4}{|l|}{ RELN } \\
\hline \multicolumn{4}{|l|}{ RORA } \\
\hline \multicolumn{4}{|l|}{ SYT17 } \\
\hline ZNF385B & & & \\
\hline
\end{tabular}

through both direct and indirect effects on target genes are expected from its haploinsufficiency. By contrast, all of the functions so far attributed to OCRL in non-neuronal cells occur at the post-translational level. As such, many of our observed DEGs could be due to secondary effects through a variety of potential OCRL-affected pathways, such as altered recycling of growth factor receptors linked to activation of transcription factors, and increases in membrane-associated phosphatidylinositol 4,5-bisphosphate $(\mathrm{PI}(4,5) \mathrm{P} 2)$, which can potentially affect protein kinase $\mathrm{C}$-mediated gene expression. Interestingly, a transcription factor binding motif analysis of the promoters of the 319 DEGs found a nominally significant enrichment of a PITX2 motif ( $p<0.05$, vs. all promoters). The expression of PITX2, which is important for the development of the anterior chamber of the eye and is a glaucoma candidate gene [111-113], was significantly reduced in the LS NPCs (Additional file 5: Table S2).

Another factor that could have limited the full potential of RNA-seq to help understand disease pathogenesis in our study is that NPCs derived from iPSCs are grown in vitro under very specific conditions, as opposed to NPCs and other neuronal cells derived from a developing brain where the full repertoire of growth factors and cell-cell interactions that might affect NPC differentiation and gene expression potentially influenced by $O C R L$ could come into play. Testing this hypothesis in mammalian brains will have to await the development of a suitable mouse model that recapitulates the neurodevelopmental features of LS.

Finally, the number of DEGs might have been reduced because of differences in $O C R L$ expression in the three LS NPC samples. Although all three patients have mutations in the ASH-RhoGAP binding domains that generally produce hypomorphic variants, expression of LS500 is substantially lower than his brother and the other LS/control samples (Additional file 5: Table S2). This was confirmed by qPCR (Fig. 5, top panel). The decrease in OCRL mRNA in LS500 is most likely due to nonsense-mediated decay, and is accompanied by a marked decrease in OCRL protein (Fig. 5, bottom panel). These observations suggest that producing a truncated, dysfunctional OCRL protein may have additional effects on gene expression and other phenotypes compared with a simple reduction in OCRL protein levels. This could help explain phenotypic differences seen in LS patients. For example, while every patient has the triad of congenital cataracts, IDD, and renal proximal tubular dysfunction, subgroups of patients have epilepsy, stereotypical behaviors, and glaucoma. In addition, this hypothesis could also help explain the more dramatic clinical differences seen in LS and patients with OCRLassociated DENT-2 disease, the latter of which is characterized by renal disease, without eye and behavioral manifestations [114-117]. In addition, we previously found differences in the production of F-actin and WAVE-1 in LS NPCs compared with NPCs made from a null OCRL iPSC line that we generated using CRISPRCas9 gene editing [27]. However, in that study, the LS500/LS600 pair showed the same abnormality as the other two patient/control sets. Thus, other factors need to be invoked to help explain the clinical and molecular heterogeneity seen in LS and DENT-2 disease, such as genetic background. Generating additional patientspecific lines, as well as creating null and patient-specific mutations using CRISPR-Cas9 gene editing in isogenic lines to control for genetic background, will be needed to sort through these intriguing possibilities.

We presented our results by a combined analysis of the patient and control NPCs. We have also tried to 


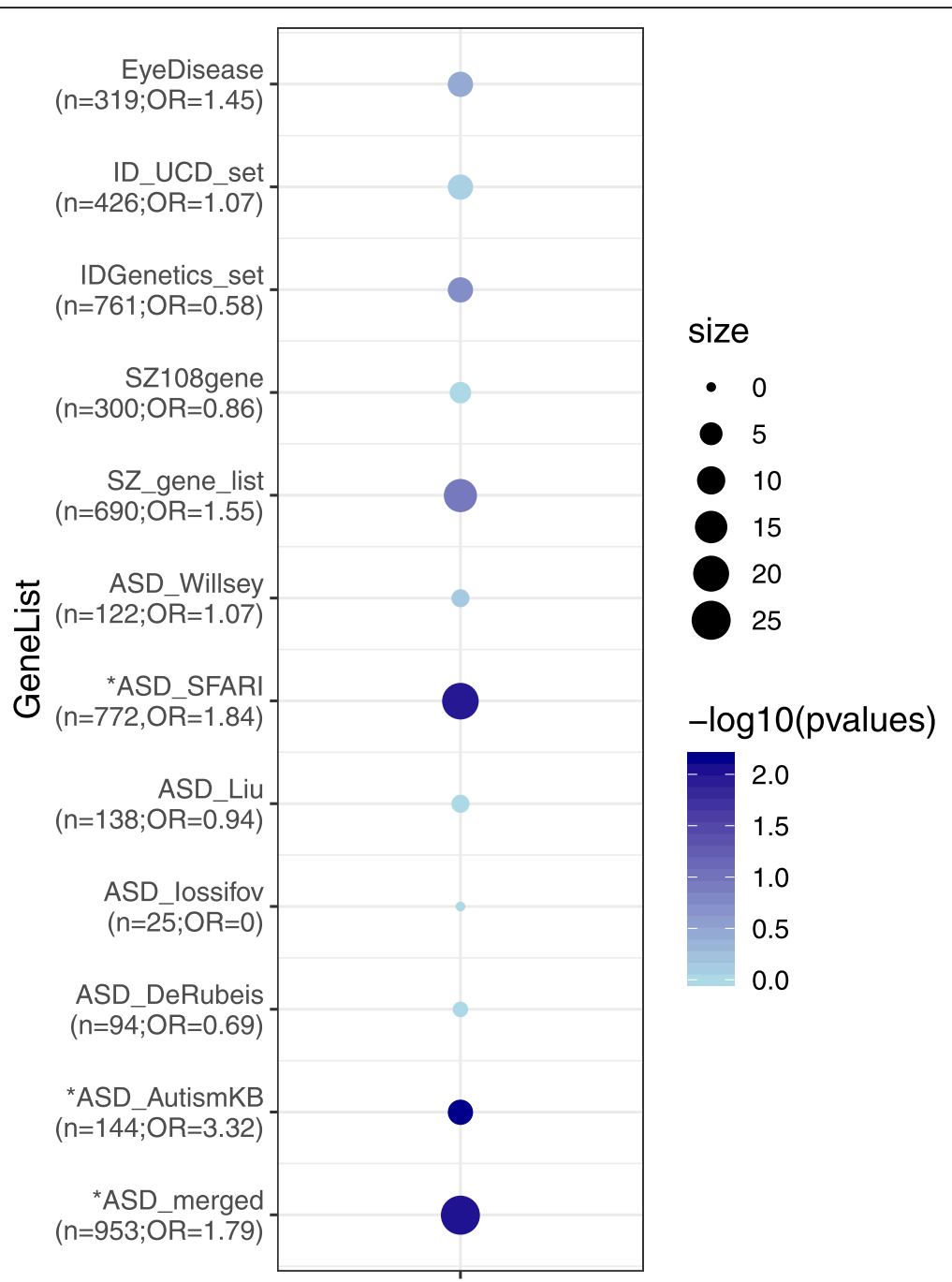

Fig. 2 Overlap of 319 nominal DEGs with genes implicated in autism spectrum disorders (ASD), schizophrenia (SZ), intellectual disability (ID), and eye disease. See main text for references and web sites. The size of the circles corresponds to the number of DEGs that overlap with diseaseassociated genes in the various data sets, while the color intensity corresponds to the -log10 ( $p$ value) from Fisher's test. The $n$ is the number of genes expressed in our NPC samples; OR is odds ratio; * denotes $p<0.05$

identify DEGs between the LS samples and controls of each family. The sample size was small $(n=2)$, thus statistical power is weak, but a few thousand DEGs were detected at fold change $>2$ and adjusted $p<0.05$ between LS and their corresponding sibling NPC controls (data not shown). The overlap of the DEGs from the three families, however, was relatively small, indicating a high level of gene expression variation in these NPC samples. Additional LS/control sets, analysis of multiple clones from the same subjects, and analyzing isogenic control/CRISPR-edited lines will be needed to resolve this issue. We are currently generating such lines.

As an alternative to DESeq2, we also applied the limma voom differentiation expression analysis [118] to the jointed analysis of our samples, using its
"duplicateCorrelation" function to account for two replicates per iPSC line. However, it did not yield DEGs by our statistical criteria of padj $<0.05$ (data not shown).

Despite the lack of highly enriched pathways from our DEG analysis, a number of interesting candidate genes emerged that strongly suggest a role in the neurodevelopmental and eye problems associated with LS, and cellular phenotypes we previously identified in NPCs. As noted in the results section, four out of the top 16 DEGs genes are known SZ, ASD, IDD candidate genes (DPP10, GDA, PITX2, SPON1), and overall, there was a significant overlap between the 319 DEGs and ASD candidate genes (Fig. 2).

Two other DEGs of note are TMEM132C and TMEM132D, which are feasible candidates for the F- 


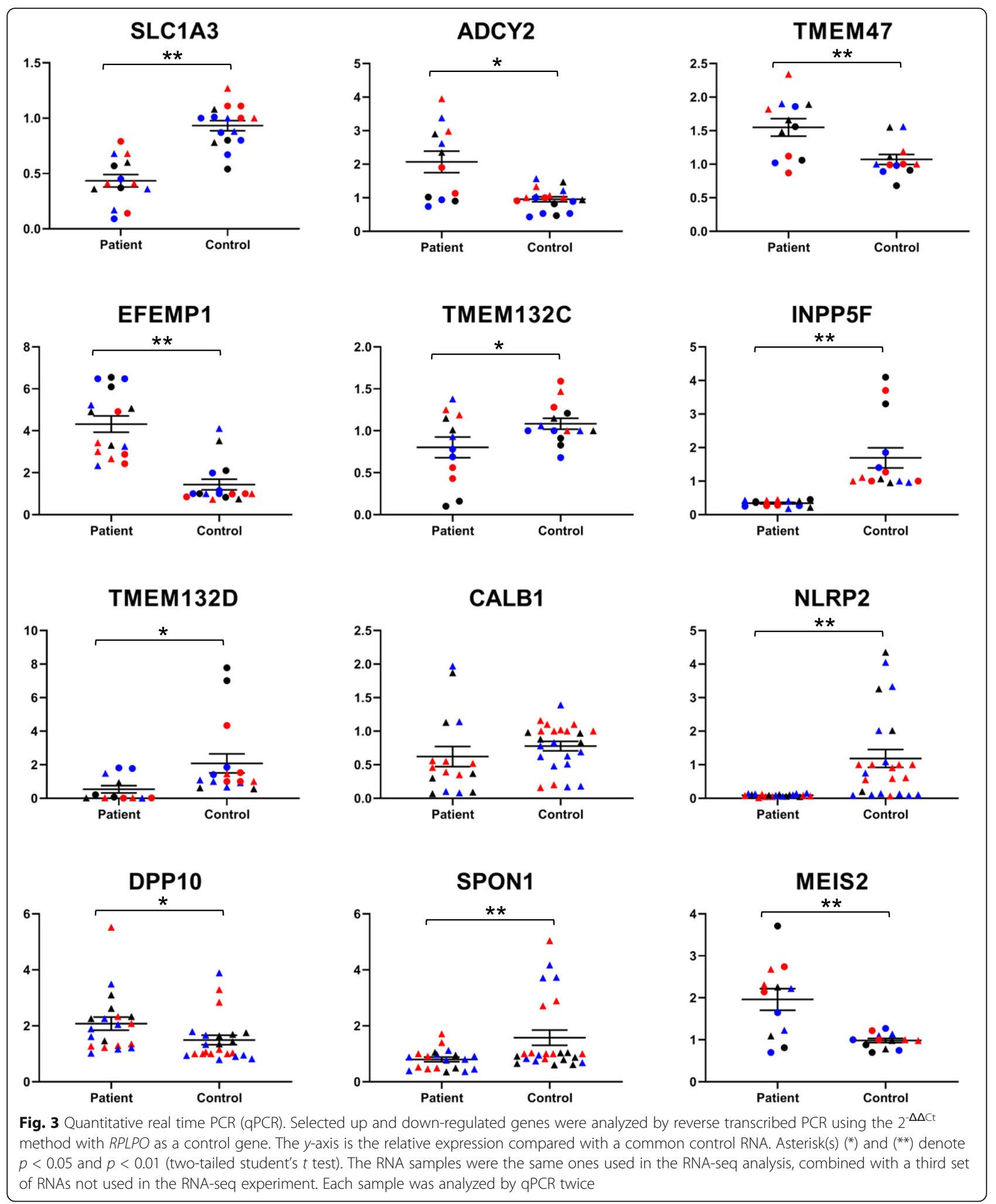

actin/WAVE1 abnormalities we previously found in LS NPCs [27]. These genes code for members of a family of transmembrane, cell-surface molecules expressed in the brain [119]. TMEM132 proteins have an intracellular
WAVE regulatory complex interacting receptor sequence cytoplasmic motif, which is a key regulator of actin polymerization by initiating F-actin nucleation through an interaction with the Arp2/3 complex [120]. 

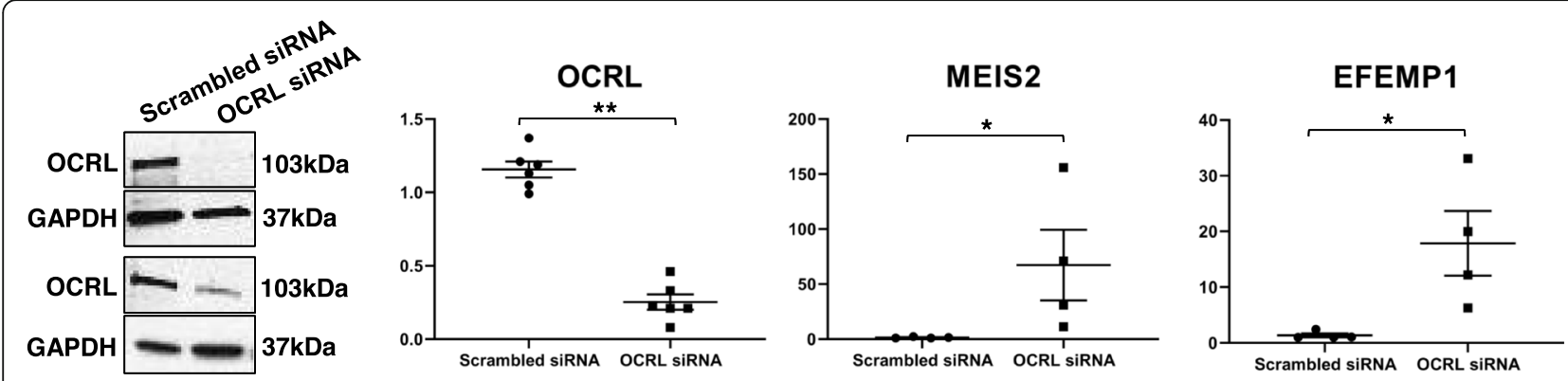

Fig. 4 OCRL knockdown. Left panel shows a western blot of OCRL along with a control protein, GAPDH, after NPCs were exposed to an OCRL siRNA and a scrambled control. Two independent KD experiments were carried out. The right three panels are qPCR results for OCRL, MEIS2 and EFEMP1 carried out on two independent RNA samples, both analyzed in duplicate, as described in the methods section an in the Fig. 3 legend

Whether TMEM132 proteins affect WAVE-1 expression in LS NPCs remains to be determined.

One of the more interesting findings in the NPC transcriptome analysis are the DEGs implicated in eye pathology. This could represent differential expression in eye tissue that happen to be similarly affected in neural cells, or to common developmental pathways, although this remains to be determined. On the other hand, recent research suggests that some forms of glaucoma should be viewed as neurodegenerative disorders caused by retinal and optic nerve injury $[121,122]$, so it is possible that the primary defect

\section{OCRL RNA}

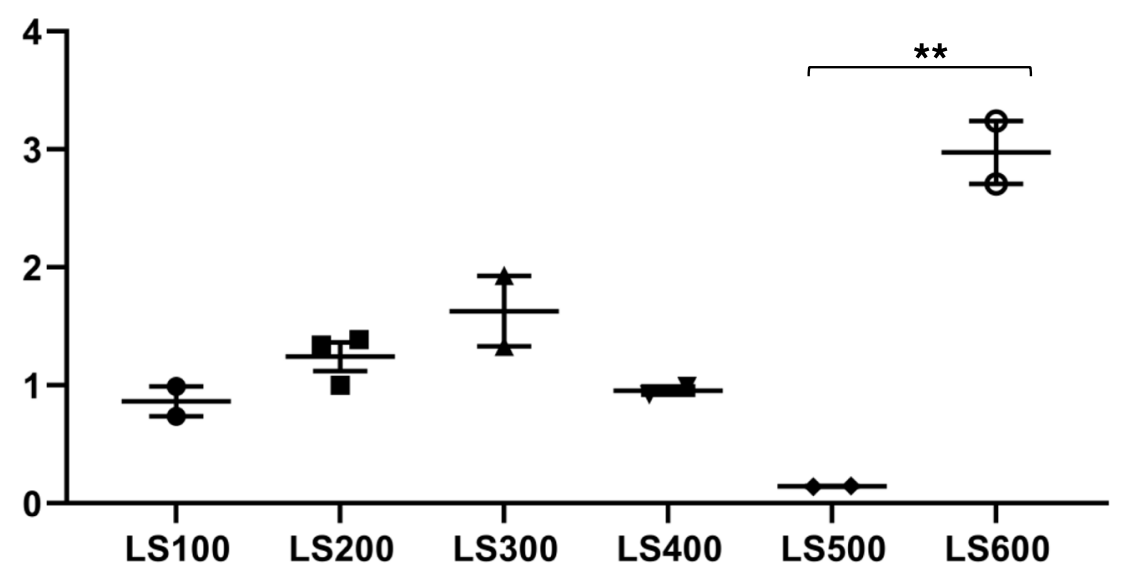

\section{OCRL Protein}

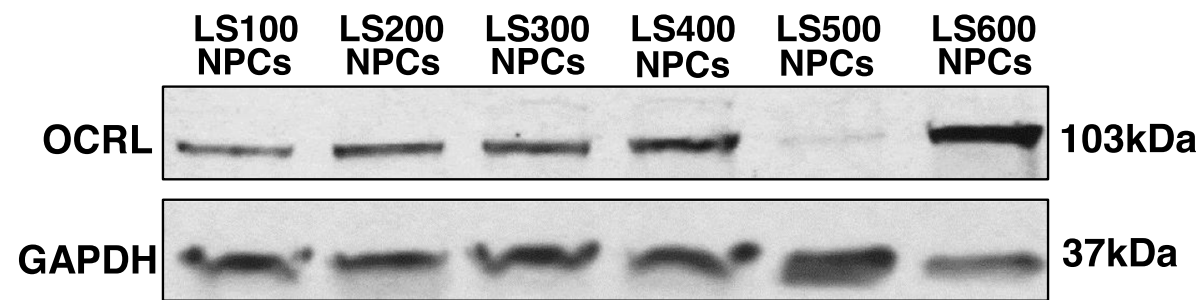

Fig. 5 OCRL protein and RNA. OCRL RNA was analyzed by qPCR (top) as described in the Fig. 3 legend. OCRL protein (bottom) was analyzed by Western blotting, as described in the methods section. The Western blot was done twice with two independent samples 
related to these DEGs is due to aberrant expression in neuronal cells.

The most significant DEGs related to LS eye pathology are EFEMP1, MEIS2, and SPON1I, as noted above. EFEMP1 is particularly interesting from a therapeutic perspective because it is connected to several potentially druggable pathways, including complement activation, the EGF receptor, and BMP7 and TGF $\beta 2$ signaling [110, 123-125]. In addition, EFEMP1, as a protein secreted into the extracellular matrix, could be a target for therapeutic intervention as well.

With respect to EFEMP1, MEIS2, and SPON1, and glaucoma risk in LS, the fact that these genes have been implicated in glaucoma and other eye disorders suggests that understanding how they cause severe eye disease in LS could have much broader public health implications, considering the high prevalence of these conditions in the general population. Thus, the iPSC lines we have developed could be very useful for screening small molecule modulators of EFEMP1 and other eye-related DEGs for a wide range of eye disorders. Their role in eye pathology can now be analyzed in our iPSC model system since several protocols have been published for inducing differentiation into various types of eye tissues $[126,127]$.

\section{Limitations}

A limitation of the study is the sample size, which is a general limiting factor for most iPSC studies, considering the expense and time it takes to cultivate these lines. In addition, there is a dearth of protein and functional validation, which means that individual DEG findings may ultimately fail to be biologically relevant. Nevertheless, our findings are still of great interest because the differentially expressed genes are consistent with what is known about LS with respect to both neurodevelopmental and eye pathologies. We plan on increasing our sample size in the next year to improve the scientific rigor of future transcriptomic studies.

\section{Conclusions}

RNA-seq analysis of iPSC-derived NPCs from patients with Lowe syndrome and their typically developing brothers identified 319 DEGs, which are enriched with genes that have been identified as ASD candidates. In addition, several DEGs code for genes that have been implicated in the development of cataracts, glaucoma, and retinal disease. Altered expression of these genes may play a role in the behavioral and ocular problems occurring in LS and connect this extremely rare condition at a pathophysiological level to a much wider population of disorders. The study also points to several feasible targets for therapeutic intervention.

\section{Supplementary information}

Supplementary information accompanies this paper at https://doi.org/10. 1186/s11689-020-09317-2.

Additional file 1: Figure S1. Immunocytochemistry (ICC) of NPCs used in the RNA-seq study (one set) showing Vimentin and Sox2 staining (A and $B$, respectively) with a nuclear stain (DAPI).

Additional file 2: Figure S2. Pearson's correlation coefficients of the gene expression between NPCs described in the current study and 300 samples from the ENCODE project. Samples with coefficients $>0.85$ are shown and the highest correlations are NPCS from ENCODE

(ENCFF663ARH), followed by a human neuroblastoma cell line, SK-N-DZ.

Additional file 3: Table S1. Quality of RNA-seq Reads and Mapping. The number of reads, alignment rates, and reads across different gene regions are similar. The instrument ID, run number, lane number and flowcell ID were provided by the Novogene.

Additional file 4: Figure S3. A and B. Sashimi plots of RNA-seq reads confirming cryptic splice in exon 24 in LS100, and loss of exon 23 in LS200, as described in Barnes et al. C. shows deletion of " $C$ " in exon 20 in LS500.

Additional file 5:Table S2. Entire gene list arranged in descending order of significance level (pval), The top 16 genes with padj $<0.1$ are in bold type.

Additional file 6: Figure S4. Gene Set Enrichment Analysis (GSEA) for genes that are up-regulated in controls (down-regulated in LS). GO terms were selected by nominal pval $<0.01$ because none passed FDR $<25 \%$.

Additional file 7: Table S3. Overlap of nominal DEGs with ASD, ID, SZ and eye disease gene datasets. Citations are included in the table.

\section{Abbreviations}

DEG: Differentially expressed gene; FPKM: Fragments per kilobase of exon per million fragments mapped; FDR: False discovery rate; GO: Gene ontology; GWAS: Genome-wide association study; iPSC: Induced pluripotent stem cell; KO: Knockout; NPC: Neural progenitor cell; PCR: Polymerase chain reaction; qPCR: Quantitative real-time PCR; Pval: P value; ASD: Autism spectrum disorders; SZ: Schizophrenia; BD: Bipolar disorder; ICC: Immunocytochemistry; $\mathrm{PI}(4,5) \mathrm{P} 2$ : Phosphatidylinositol 4,5-bisphosphate; IRB: Internal review board

\section{Acknowledgements}

We are grateful to the New York State Department of Health (NYSTEM Program) for supporting the Einstein Comprehensive Human Pluripotent Stem Cell Center under the direction of Dr. Eric Bouhassira (NYSTEM C029154). The authors would also like to thank the participating families and Yang Sun, MD, PhD, for providing the RPE cell line.

\section{Authors' contributions}

HL contributed in bioinformatics, data analysis, and manuscript preparation; JB conceived experiment, NPC cultures, protein isolation, and Western blotting; EP contributed in iPSC cultures and RNA isolation qPCR; $\mathrm{NH}$ contributed in $\mathrm{qPCR}$; CB contributed in immunohistochemistry; FS contributed in literature search and preparation of tables; PW contributed in bioinformatics and data analysis; DZ contributed in bioinformatics, data analysis, and manuscript preparation; and HML conceived the experiment, manuscript preparation, and data analysis. All authors read and approved the final manuscript.

\section{Funding}

This project was supported by pilot grants from the Lowe Syndrome Association and the Lowe Syndrome Foundation. HML is supported by a grant from NIMH National Institute of Mental Health (NIMH) (MH099427). This work was also supported in part by a grant to The Rose F. Kennedy Intellectual and Developmental Disabilities Research Center (RFK-IDDRC) from the Eunice Kennedy Shriver National Institute of Child Health \& Human Development (NICHD) at the NIH (1P30HD071593), and NICHD grant 6 U54 HD 090260. JB is supported by The Einstein Training Program in Stem Cell Research of Albert Einstein College of Medicine, Inc. from the Empire State Stem Cell Fund through New York State Department of Health Contract C30292GG. Opinions expressed here are solely those of the author and do 
not necessarily reflect those of the Empire State Stem Cell Board, the New York State Department of Health, or the State of New York.

\section{Availability of data and materials}

RNA-seq data can be accessed at the Gene Expression Omnibus (GEO), (https://www.ncbi.nlm.nih.gov/geo/), accession number GSE129310, review token, yzuluyoyrtavdkr.

\section{Ethics approval and consent to participate}

The study and consent forms were approved by the Albert Einstein College of Medicine Institutional Review Board (IRB). Consent was obtained by a skilled member of the research team who had received prior human subjects training

\section{Consent for publication}

Consent to publish findings and data was provided in the consent form, which was signed by all participants.

\section{Competing interests}

None.

\section{Author details}

'Department of Genetics, Albert Einstein College of Medicine, Bronx, New York, USA. ${ }^{2}$ Department of Psychiatry and Behavioral Sciences, Albert Einstein College of Medicine, Bronx, New York, USA. ${ }^{3}$ Dominick P Purpura Department of Neuroscience, Albert Einstein College of Medicine, Bronx, New York, USA. ${ }^{4}$ Department of Neurology, Albert Einstein College of Medicine, Bronx, New York, USA. ${ }^{5}$ Department of Medicine, Albert Einstein College of Medicine, Bronx, New York, USA.

\section{Received: 16 October 2019 Accepted: 28 April 2020}

\section{Published online: 11 May 2020}

\section{References}

1. Silver DN, Lewis RA, Nussbaum RL. Mapping the Lowe oculocerebrorenal syndrome to $\mathrm{Xq24-q26}$ by use of restriction fragment length polymorphisms. J Clin Invest. 1987:79(1):282-5.

2. Schurman SJ, Scheinman SJ. Inherited cerebrorenal syndromes. Nat Rev Nephrol. 2009;5(9):529-38.

3. Waugh MG. PIPs in neurological diseases. Biochim Biophys Acta. 2015; 1851(8):1066-82.

4. Staiano L, De Leo MG, Persico M, De Matteis MA. Mendelian disorders of PI metabolizing enzymes. Biochim Biophys Acta. 2015;1851(6):867-81.

5. Lewis RA, Nussbaum RL, Brewer ED. Lowe syndrome. In GeneReviews(R). Edited by Adam MP, Ardinger HH, Pagon RA, et al. Seattle (WA): University of Washington, Seattle. GeneReviews is a registered trademark of the University of Washington, Seattle. All rights reserved; 1993.

6. De Matteis MA, Staiano L, Emma F, Devuyst O. The 5-phosphatase OCRL in Lowe syndrome and Dent disease 2. Nat Rev Nephrol. 2017;13(8):455-70.

7. Prosseda PP, Luo N, Wang B, Alvarado JA, Hu Y, Sun Y. Loss of OCRL increases ciliary PI(4,5)P2 in Lowe oculocerebrorenal syndrome. J Cell Sci. 2017;130(20):3447-54.

8. Luo N, Conwell MD, Chen X, Kettenhofen Cl, Westlake CJ, Cantor LB, et al. Primary cilia signaling mediates intraocular pressure sensation. Proc Natl Acad Sci U S A. 2014:111(35):12871-6.

9. Inoue K, Balkin DM, Liu L, Nandez R, Wu Y, Tian X, et al. Kidney tubular ablation of Ocrl/Inpp5b Phenocopies Lowe syndrome Tubulopathy. J Am Soc Nephrol. 2017;28(5):1399-407.

10. Nakatsu F, Messa M, Nandez R, Czapla H, Zou Y, Strittmatter SM, De Camilli P. Sac2/INPP5F is an inositol 4-phosphatase that functions in the endocytic pathway. J Cell Biol. 2015;209(1):85-95.

11. Vicinanza M, Di Campli A, Polishchuk E, Santoro M, Di Tullio G, Godi A, Levtchenko E, De Leo MG, Polishchuk R, Sandoval L, Marzolo MP, De Matteis MA. OCRL controls trafficking through early endosomes via Ptdlns4,5P(2)dependent regulation of endosomal actin. EMBO J. 2011;30(24):4970-85.

12. McCrea HJ, Paradise S, Tomasini L, Addis M, Melis MA, De Matteis MA, De Camilli P. All known patient mutations in the ASH-RhoGAP domains of OCRL affect targeting and APPL1 binding. Biochem Biophys Res Commun. 2008;369(2):493-9.

13. Nandez R, Balkin DM, Messa M, Liang L, Paradise S, Czapla H, Hein MY, Duncan JS, Mann M, De Camilli P. A role of OCRL in clathrin-coated pit dynamics and uncoating revealed by studies of Lowe syndrome cells. Elife. 2014;3:e02975

14. Pirruccello M, De Camilli P. Inositol 5-phosphatases: insights from the Lowe syndrome protein OCRL. Trends Biochem Sci. 2012;37(4):134-43.

15. Zhang $X$, Jefferson $A B$, Auethavekiat $V$, Majerus PW. The protein deficient in Lowe syndrome is a phosphatidylinositol-4,5-bisphosphate 5-phosphatase Proc Natl Acad Sci U S A. 1995;92(11):4853-6.

16. Zhang X, Hartz PA, Philip E, Racusen LC, Majerus PW. Cell lines from kidney proximal tubules of a patient with Lowe syndrome lack OCRL inositol polyphosphate 5-phosphatase and accumulate phosphatidylinositol 4,5bisphosphate. J Biol Chem. 1998;273(3):1574-82.

17. Madhivanan K, Ramadesikan S, Aguilar RC. Role of Ocrl1 in primary cilia assembly. Int Rev Cell Mol Biol. 2015;317:331-47.

18. Rbaibi Y, Cui S, Mo D, Carattino M, Rohatgi R, Satlin LM, Szalinski CM, Swanhart LM, Folsch H, Hukriede NA, Weisz OA. OCRL1 modulates cilia length in renal epithelial cells. Traffic. 2012;13(9):1295-305.

19. Luo N, West CC, Murga-Zamalloa CA, Sun L, Anderson RM, Wells CD, Weinreb RN, Travers JB, Khanna H, Sun Y. OCRL localizes to the primary cilium: a new role for cilia in Lowe syndrome. Hum Mol Genet. 2012;21(15):3333-44.

20. Sharma S, Skowronek A, Erdmann KS. The role of the Lowe syndrome protein OCRL in the endocytic pathway. Biol Chem. 2015;396(12):1293-300.

21. Ungewickell A, Ward ME, Ungewickell E, Majerus PW. The inositol polyphosphate 5-phosphatase Ocrl associates with endosomes that are partially coated with clathrin. Proc Natl Acad Sci U S A. 2004;101(37):13501-6.

22. Ramirez IB, Pietka G, Jones DR, Divecha N, Alia A, Baraban SC, Hurlstone AF, Lowe M. Impaired neural development in a zebrafish model for Lowe syndrome. Hum Mol Genet. 2012;21(8):1744-59.

23. Suchy SF, Nussbaum RL. The deficiency of PIP2 5-phosphatase in Lowe syndrome affects actin polymerization. Am J Hum Genet. 2002;71(6):1420-7.

24. Bothwell SP, Chan E, Bernardini IM, Kuo YM, Gahl WA, Nussbaum RL. Mouse model for Lowe syndrome/Dent disease 2 renal tubulopathy. J Am Soc Nephrol. 2011;22(3):443-8.

25. Janne PA, Suchy SF, Bernard D, MacDonald M, Crawley J, Grinberg A, WynshawBoris A, Westphal H, Nussbaum RL. Functional overlap between murine Inpp5b and Ocrl1 may explain why deficiency of the murine ortholog for OCRL1 does not cause Lowe syndrome in mice. J Clin Invest. 1998;101(10):2042-53.

26. Festa BP, Berquez M, Gassama A, Amrein I, Ismail HM, Samardzija M, Staiano L, Luciani A, Grimm C, Nussbaum RL, De Matteis MA, Dorchies OM, Scapozza L, Wolfer DP, Devuyst O: OCRL Deficiency impairs endolysosomal function in a humanized mouse model for Lowe syndrome and Dent disease. Hum Mol Genet 2018.

27. Barnes J, Salas F, Mokhtari R, Dolstra H, Pedrosa E, Lachman HM: Modeling the neuropsychiatric manifestations of Lowe syndrome using induced pluripotent stem cells: defective F-actin polymerization and WAVE-1 expression in neuronal cells. Mol Autism 2018, 9;44 doi: https://doi.org/10. 1186/s13229-018-0227-3. eCollection 2018.

28. Wang P, Mokhtari R, Pedrosa E, Kirschenbaum M, Bayrak C, Zheng D, Lachman HM: CRISPR/Cas9-mediated heterozygous knockout of the autism gene CHD8 and characterization of its transcriptional networks in cerebral organoids derived from iPS cells. Mol Autism 2017, 8;11 doi: https://doi.org/ 10.1186/s13229-017-0124-1. eCollection 2017.

29. Zhao D, Mokhtari R, Pedrosa E, Birnbaum R, Zheng D, Lachman HM: Transcriptome analysis of microglia in a mouse model of Rett syndrome: differential expression of genes associated with microglia/macrophage activation and cellular stress. Mol Autism 2017, 8;17 doi: https://doi.org/10. 1186/s13229-017-0134-z. eCollection 2017.

30. Wang $P$, Lin M, Pedrosa E, Hrabovsky A, Zhang Z, Guo W, Lachman HM, Zheng D: CRISPR/Cas9-mediated heterozygous knockout of the autism gene CHD8 and characterization of its transcriptional networks in neurodevelopment. Mol Autism 2015, 6;55 doi: https://doi.org/10.1186/ s13229-015-0048-6. eCollection 2015.

31. Camp JG, Badsha F, Florio M, Kanton S, Gerber T, Wilsch-Brauninger M, Lewitus E, Sykes A, Hevers W, Lancaster M, Knoblich JA, Lachmann R, Paabo $S$, Huttner WB, Treutlein B. Human cerebral organoids recapitulate gene expression programs of fetal neocortex development. Proc Natl Acad Sci U S A. 2015;112(51):15672-7.

32. Mariani J, Coppola G, Zhang P, Abyzov A, Provini L, Tomasini L, Amenduni M, Szekely A, Palejev D, Wilson M, Gerstein M, Grigorenko EL, Chawarska K, Pelphrey KA, Howe JR, Vaccarino FM. FOXG1-dependent dysregulation of GABA/glutamate neuron differentiation in autism spectrum disorders. Cell. 2015;162(2):375-90. 
33. Lin M, Lachman HM, Zheng D. Transcriptomics analysis of iPSC-derived neurons and modeling of neuropsychiatric disorders. Mol Cell Neurosci. 2016;73:32-42

34. O'Shea KS, McInnis MG. Neurodevelopmental origins of bipolar disorder: iPSC models. Mol Cell Neurosci. 2016;73:63-83.

35. Zhang ZN, Freitas BC, Qian H, Lux J, Acab A, Trujillo CA, Herai RH, Nguyen Huu VA, Wen JH, Joshi-Barr S, Karpiak JV, Engler AJ, Fu XD, Muotri AR, Almutairi A. Layered hydrogels accelerate iPSC-derived neuronal maturation and reveal migration defects caused by MeCP2 dysfunction. Proc Natl Acad Sci U S A. 2016;113(12):3185-90.

36. Olivier E, Qiu C, Bouhassira EE. Novel, high-yield red blood cell production methods from CD34-positive cells derived from human embryonic stem, yolk sac, fetal liver, cord blood, and peripheral blood. Stem Cells Transl Med. 2012;1(8):604-14

37. Davis CA, Hitz BC, Sloan CA, Chan ET, Davidson JM, Gabdank I, Hilton JA, Jain K, Baymuradov UK, Narayanan AK, Onate KC, Graham K, Miyasato SR, Dreszer TR, Strattan JS, Jolanki O, Tanaka FY, Cherry JM. The encyclopedia of DNA elements (ENCODE): data portal update. Nucleic Acids Res. 2018; 46(D1):D794-801.

38. Kim D, Langmead B, Salzberg SL. HISAT: a fast spliced aligner with low memory requirements. Nat Methods. 2015;12(4):357-60.

39. Anders S, Pyl PT, Huber W. HTSeq--a python framework to work with highthroughput sequencing data. Bioinformatics. 2015;31(2):166-9.

40. Pertea M, Pertea GM, Antonescu CM, Chang TC, Mendell JT, Salzberg SL. StringTie enables improved reconstruction of a transcriptome from RNA-seq reads. Nat Biotechnol. 2015;33(3):290-5.

41. Harrow J, Frankish A, Gonzalez JM, Tapanari E, Diekhans M, Kokocinski F, Aken BL, Barrell D, Zadissa A, Searle S, Barnes I, Bignell A, Boychenko V, Hunt T, Kay M, Mukherjee G, Rajan J, Despacio-Reyes G, Saunders G, Steward C, Harte R, Lin M, Howald C, Tanzer A, Derrien T, Chrast J, Walters N, Balasubramanian S, Pei B, Tress M, Rodriguez JM, Ezkurdia I, van Baren J, Brent M, Haussler D, Kellis M, Valencia A, Reymond A, Gerstein M, Guigo R, Hubbard TJ. GENCODE: the reference human genome annotation for The ENCODE Project. Genome Res. 2012;22(9):1760-74.

42. Love MI, Huber W, Anders S. Moderated estimation of fold change and dispersion for RNA-seq data with DESeq2. Genome Biol. 2014;15(12):550.

43. Chen J, Lin M, Hrabovsky A, Pedrosa E, Dean J, Jain S, Zheng D, Lachman HM. ZNF804A transcriptional networks in differentiating neurons derived from induced pluripotent stem cells of human origin. PLoS One. 2015;10(4): e0124597.

44. Subramanian A, Tamayo P, Mootha VK, Mukherjee S, Ebert BL, Gillette MA, Paulovich A, Pomeroy SL, Golub TR, Lander ES, Mesirov JP. Gene set enrichment analysis: a knowledge-based approach for interpreting genomewide expression profiles. Proc Natl Acad Sci U S A. 2005;102(43):15545-50.

45. Mootha VK, Lindgren CM, Eriksson KF, Subramanian A, Sihag S, Lehar J, Puigserver P, Carlsson E, Ridderstrale M, Laurila E, Houstis N, Daly MJ, Patterson N, Mesirov JP, Golub TR, Tamayo P, Spiegelman B, Lander ES, Hirschhorn JN, Altshuler D, Groop LC. PGC-1alpha-responsive genes involved in oxidative phosphorylation are coordinately downregulated in human diabetes. Nat Genet. 2003;34(3):267-73.

46. Abrahams BS, Arking DE, Campbell DB, Mefford HC, Morrow EM, Weiss LA, Menashe I, Wadkins T, Banerjee-Basu S, Packer A. SFARI Gene 2.0: a community-driven knowledgebase for the autism spectrum disorders (ASDs). Mol Autism. 2013;4(1):36. https://doi.org/10.1186/2040-2392-4-36.

47. Iossifov I, O'Roak BJ, Sanders SJ, Ronemus M, Krumm N, Levy D, Stessman HA, Witherspoon KT, Vives L, Patterson KE, Smith JD, Paeper B, Nickerson DA, Dea J, Dong S, Gonzalez LE, Mandell JD, Mane SM, Murtha MT, Sullivan CA, Walker MF, Waqar Z, Wei L, Willsey AJ, Yamrom B, Lee YH, Grabowska E, Dalkic E, Wang Z, Marks S, Andrews P, Leotta A, Kendall J, Hakker I, Rosenbaum J, Ma B, Rodgers L, Troge J, Narzisi G, Yoon S, Schatz MC, Ye K, WR MC, Shendure J, Eichler EE, State MW, Wigler M. The contribution of de novo coding mutations to autism spectrum disorder. Nature. 2014; 515(7526):216-21.

48. Xu LM, Li JR, Huang Y, Zhao M, Tang X, Wei L. AutismKB: an evidence-based knowledgebase of autism genetics. Nucleic Acids Res. 2012;40(Database issue):D1016-22.

49. Willsey AJ, Sanders SJ, Li M, Dong S, Tebbenkamp AT, Muhle RA, Reilly SK, Lin L, Fertuzinhos S, Miller JA, Murtha MT, Bichsel C, Niu W, Cotney J, ErcanSencicek AG, Gockley J, Gupta AR, Han W, He X, Hoffman EJ, Klei L, Lei J, Liu W, Liu L, Lu C, Xu X, Zhu Y, Mane SM, Lein ES, Wei L, Noonan JP, Roeder K, Devlin B, Sestan N, State MW. Coexpression networks implicate human midfetal deep cortical projection neurons in the pathogenesis of autism. Cell. 2013;155(5):997-1007.

50. Liu L, Lei J, Sanders SJ, Willsey AJ, Kou Y, Cicek AE, Klei L, Lu C, He X, Li M, Muhle RA, Ma'ayan A, Noonan JP, Sestan N, McFadden KA, State MW, Buxbaum JD, Devlin B, Roeder K. DAWN: a framework to identify autism genes and subnetworks using gene expression and genetics. Mol Autism. 2014;5(1):22. https://doi.org/10.1186/2040-2392-5-22.

51. De Rubeis $S$, He X, Goldberg AP, Poultney CS, Samocha K, Cicek AE, Kou Y, Liu L, Fromer M, Walker S, Singh T, Klei L, Kosmicki J, Shih-Chen F, Aleksic B, Biscaldi M, Bolton PF, Brownfeld JM, Cai J, Campbell NG, Carracedo A, Chahrour MH, Chiocchetti AG, Coon H, Crawford EL, Curran SR, Dawson G, Duketis E, Fernandez BA, Gallagher L, Geller E, Guter SJ, Hill RS, lonita-Laza J, Jimenz Gonzalez P, Kilpinen H, Klauck SM, Kolevzon A, Lee I, Lei I, Lei J, Lehtimaki T, Lin CF, Ma'ayan A, Marshall CR, AL MI, Neale B, Owen MJ, Ozaki N, Parellada M, Parr JR, Purcell S, Puura K, Rajagopalan D, Rehnstrom K, Reichenberg A, Sabo A, Sachse M, Sanders SJ, Schafer C, Schulte-Ruther M, Skuse D, Stevens C, Szatmari P, Tammimies K, Valladares O, Voran A, Li-San W, Weiss LA, Willsey AJ, Yu TW, Yuen RK, DDD Study, Homozygosity Mapping Collaborative for Autism, UK10K Consortium, Cook EH, Freitag CM, Gill M, Hultman CM, Lehner T, Palotie A, Schellenberg GD, Sklar P, State MW Sutcliffe JS, Walsh CA, Scherer SW, Zwick ME, Barett JC, Cutler DJ, Roeder K, Devlin B, Daly MJ, Buxbaum JD. Synaptic, transcriptional and chromatin genes disrupted in autism. Nature. 2014;515(7526):209-15.

52. Allen NC, Bagade S, McQueen MB, loannidis JP, Kawoura FK, Khoury MJ, Tanzi RE, Bertram L. Systematic meta-analyses and field synopsis of genetic association studies in schizophrenia: the SzGene database. Nat Genet. 2008:40(7):827-34.

53. Schizophrenia Working Group of the Psychiatric Genomics Consortium. Biological insights from 108 schizophrenia-associated genetic loci. Nature. 2014;511(7510):421-7.

54. Fatima A, Faroog $M$, Abdullah U, Tariq M, Mustafa T, Iqbal $M$, Tommerup $N$, Mahmood Baig S. Genome-wide supported risk variants in MIR137, CACN A1C, CSMD1, DRD2, and GRM3 contribute to schizophrenia susceptibility in Pakistani population. Psychiatry Investig. 2017;14(5):687-92.

55. Ortega-Alonso A, Ekelund J, Sarin AP, Miettunen J, Veijola J, Jarvelin MR, Hennah W: Genome-wide association study of psychosis proneness in the Finnish population. Schizophr Bull 2017

56. Hamshere ML, Walters JT, Smith R, Richards AL, Green E, Grozeva D, Jones I, Forty L, Jones L, Gordon-Smith K, Riley B, O'Neill FA, Kendler KS, Sklar P, Purcell S, Kranz J, Schizophrenia psychiatric genome-wide association study consortium, Wellcome Trust Case Control Consortium+, Wellcome Trust Case Control Consortium 2, Morris D, Gill M, Holmans P, Craddock N, Corvin A, Owen MJ, O'Donovan MC. Genome-wide significant associations in schizophrenia to ITIH3/4, CACNA1C and SDCCAG8, and extensive replication of associations reported by the Schizophrenia PGC. Mol Psychiatry. 2013; 18(6):708-12.

57. Lett TA, Zai CC, Tiwari AK, Shaikh SA, Likhodi O, Kennedy JL, Muller DJ. ANK3, CACNA1C and ZNF804A gene variants in bipolar disorders and psychosis subphenotype. World J Biol Psychiatry. 2011;12(5):392-7.

58. Sklar P, Smoller JW, Fan J, Ferreira MA, Perlis RH, Chambert K, Nimgaonkar VL, McQueen MB, Faraone SV, Kirby A, de Bakker PI, Ogdie MN, Thase ME, Sachs GS, Todd-Brown K, Gabriel SB, Sougnez C, Gates C, Blumenstiel B, Defelice M, Ardlie KG, Franklin J, Muir WJ, McGhee KA, Macintyre DJ, McLean A, Vanbeck M, McQuillin A, Bass NJ, Robinson M, Lawrence J, Anjorin A, Curtis D, Scolnick EM, Daly MJ, Blackwood DH, Gurling HM, Purcell SM: Whole-genome association study of bipolar disorder. Mol Psychiatry 2008.

59. Zhu D, Yin J, Liang C, Luo X, Lv D, Dai Z, Xiong S, Fu J, Li Y, Lin J, Lin Z, Wang Y, Ma G. CACNA1C (rs1006737) may be a susceptibility gene for schizophrenia: an updated meta-analysis. Brain Behav. 2019;9(6):e01292.

60. Louw JJ, Corveleyn A, Jia Y, Hens G, Gewillig M, Devriendt K. MEIS2 involvement in cardiac development, cleft palate, and intellectual disability. Am J Med Genet A. 2015;167A(5):1142-6.

61. Douglas G, Cho MT, Telegrafi A, Winter S, Carmichael J, Zackai EH, Deardorff MA, Harr M, Williams L, Psychogios A, Erwin AL, Grebe T, Retterer K, Juusola J. De novo missense variants in MEIS2 recapitulate the microdeletion phenotype of cardiac and palate abnormalities, developmental delay, intellectual disability and dysmorphic features. Am J Med Genet A. 2018; 176(9):1845-51.

62. Shimojima $\mathrm{K}$, Ondo $\mathrm{Y}$, Okamoto $\mathrm{N}$, Yamamoto T. A $15 \mathrm{q} 14$ microdeletion involving MEIS2 identified in a patient with autism spectrum disorder. Hum Genome Var. 2017:4:17029. 
63. Correia F, Cafe C, Almeida J, Mouga S, Oliveira G. Autism spectrum disorder: FRAXE mutation, a rare etiology. J Autism Dev Disord. 2015;45(3):888-92.

64. Sanchez-Sanchez SM, Magdalon J, Griesi-Oliveira K, Yamamoto GL, Santacruz-Perez C, Fogo M, Passos-Bueno MR, Sertie AL. Rare RELN variants affect Reelin-DAB1 signal transduction in autism spectrum disorder. Hum Mutat. 2018;39(10):1372-83.

65. Lammert DB, Middleton FA, Pan J, Olson EC, Howell BW. The de novo autism spectrum disorder RELN R2290C mutation reduces Reelin secretion and increases protein disulfide isomerase expression. J Neurochem. 2017; 142(1):89-102.

66. Lammert DB, Howell BW. RELN mutations in autism spectrum disorder. Front Cell Neurosci. 2016;10:84.

67. Wang Z, Hong Y, Zou L, Zhong R, Zhu B, Shen N, Chen W, Lou J, Ke J, Zhang T, Wang W, Miao X. Reelin gene variants and risk of autism spectrum disorders: an integrated meta-analysis. Am J Med Genet B Neuropsychiatr Genet. 2014;165B(2):192-200.

68. Bartnik M, Chun-Hui Tsai A, Xia Z, Cheung SW, Stankiewicz P: Disruption of the SCN2A and SCN3A genes in a patient with mental retardation, neurobehavioral and psychiatric abnormalities, and a history of infantile seizures. Clin Genet 2010.

69. Weiss LA, Escayg A, Kearney JA, Trudeau M, MacDonald BT, Mori M, Reichert J, Buxbaum JD, Meisler MH. Sodium channels SCN1A, SCN2A and SCN3A in familial autism. Mol Psychiatry. 2003;8(2):186-94.

70. Jiang $Y H$, Yuen RK, Jin X, Wang M, Chen N, Wu X, Ju J, Mei J, Shi Y, He M, Wang G, Liang J, Wang Z, Cao D, Carter MT, Chrysler C, Drmic IE, Howe JL, Lau L, Marshall CR, Merico D, Nalpathamkalam T, Thiruvahindrapuram B, Thompson A, Uddin M, Walker S, Luo J, Anagnostou E, Zwaigenbaum L, Ring $\mathrm{RH}$, Wang J, Lajonchere C, Wang J, Shih A, Szatmari P, Yang H, Dawson G, Li Y, Scherer SW. Detection of clinically relevant genetic variants in autism spectrum disorder by whole-genome sequencing. Am J Hum Genet. 2013;93(2):249-63.

71. Callaghan DB, Rogic S, Tan PPC, Calli K, Qiao Y, Baldwin R, Jacobson M, Belmadani M, Holmes N, Yu C, Li Y, Li Y, Kurtzke FE, Kuzeljevic B, Yu AY, Hudson M, Mcaughton AJM, Xu Y, Dionne-Laporte A, Girard S, Liang P, Separovic ER, Liu X, Rouleau G, Pavlidis P, Lewis MES: Whole genome sequencing and variant discovery in the ASPIRE autism spectrum disorder cohort. Clin Genet 2019.

72. Spratt PWE, Ben-Shalom R, Keeshen CM, Burke KJ,Jr, Clarkson RL, Sanders SJ, Bender KJ: The autism-associated gene Scn2a contributes to dendritic excitability and synaptic function in the prefrontal cortex. Neuron 2019.

73. Deneault E, White SH, Rodrigues DC, Ross PJ, Faheem M, Zaslavsky K, Wang Z, Alexandrova R, Pellecchia G, Wei W, Piekna A, Kaur G, Howe JL, Kwan V, Thiruvahindrapuram B, Walker S, Lionel AC, Pasceri P, Merico D, Yuen RKC, Singh KK, Ellis J, Scherer SW. Complete disruption of autism-susceptibility genes by gene editing predominantly reduces functional connectivity of isogenic human neurons. Stem Cell Reports. 2018;11(5):1211-25.

74. Sanders SJ, Campbell AJ, Cottrell JR, Moller RS, Wagner FF, Auldridge AL, Bernier RA, Catterall WA, Chung WK, Empfield JR, George AL Jr, Hipp JF, Khwaja O, Kiskinis E, Lal D, Malhotra D, Millichap JJ, Otis TS, Petrou S, Pitt G, Schust LF, Taylor CM, Tjernagel J, Spiro JE, Bender KJ. Progress in understanding and treating SCN2A-mediated disorders. Trends Neurosci. 2018;41(7):442-56.

75. Mondal K, Ramachandran D, Patel VC, Hagen KR, Bose P, Cutler DJ, Zwick ME. Excess variants in AFF2 detected by massively parallel sequencing of males with autism spectrum disorder. Hum Mol Genet. 2012;21(19):4356-64.

76. Sahoo T, Theisen A, Marble M, Tervo R, Rosenfeld JA, Torchia BS, Shaffer LG. Microdeletion of Xq28 involving the AFF2 (FMR2) gene in two unrelated males with developmental delay. Am J Med Genet A. 2011;155A(12):3110-5

77. Griswold AJ, Ma D, Cukier HN, Nations LD, Schmidt MA, Chung RH, Jaworski JM, Salyakina D, Konidari I, Whitehead PL, Wright HH, Abramson RK, Williams SM, Menon R, Martin ER, Haines JL, Gilbert JR, Cuccaro ML, Pericak-Vance MA: Evaluation of copy number variations reveals novel candidate genes in autism spectrum disorder-associated pathways. Hum Mol Genet 2012.

78. Smith EN, Bloss CS, Badner JA, Barrett T, Belmonte PL, Berrettini W, Byerley W, Coryell W, Craig D, Edenberg HJ, Eskin E, Foroud T, Gershon E, Greenwood TA, Hipolito M, Koller DL, Lawson WB, Liu C, Lohoff F, MG MI, FJ MM, Mirel DB, Murray SS, Nievergelt C, Nurnberger J, Nwulia EA, Paschall J, Potash JB, Rice J, Schulze TG, Scheftner W, Panganiban C, Zaitlen N, Zandi PP, Zollner S, Schork NJ, Kelsoe JR. Genome-wide association study of bipolar disorder in European American and African American individuals. Mol Psychiatry. 2009;14(8):755-63.
79. Mak ASL, Chiu ATG, Leung GKC, Mak CCY, Chu YWY, Mok GTK, Tang WF, Chan KYK, Tang MHY, Lau Yim ET, So KW, Tao VQ, Fung CW, Wong VCN, Uddin M, Lee SL, Marshall CR, Scherer SW, Kan ASY, Chung BHY: Use of clinical chromosomal microarray in Chinese patients with autism spectrum disorder-implications of a copy number variation involving DPP10. Mol Autism 2017, 8;31 doi: https://doi.org/10.1186/s13229-017-0136-X. eCollection 2017.

80. Djurovic S, Gustafsson O, Mattingsdal M, Athanasiu L, Bjella T, Tesli M, Agartz I, Lorentzen S, Melle I, Morken G, Andreassen OA. A genome-wide association study of bipolar disorder in Norwegian individuals, followed by replication in Icelandic sample. J Affect Disord. 2010;126(1-2):312-6.

81. Verheije R, Kupchik GS, Isidor B, Kroes HY, Lynch SA, Hawkes L, Hempel M, Gelb BD, Ghoumid J, D'Amours G, Chandler K, Dubourg C, Loddo S, Tumer Z, Shaw-Smith C, Nizon M, Shevell M, Van Hoof E, Anyane-Yeboa K, Cerbone G, Clayton-Smith J, Cogne B, Corre P, Corveleyn A, De Borre M, Hjortshoj TD, Fradin M, Gewillig M, Goldmuntz E, Hens G, Lemyre E, Journel H, Kini U, Kortum F, Le Caignec C, Novelli A, Odent S, Petit F, Revah-Politi A, Stong N, Strom TM, van Binsbergen E, DDD study, Devriendt K, Breckpot J: Heterozygous loss-of-function variants of MEIS2 cause a triad of palatal defects, congenital heart defects, and intellectual disability. Eur J Hum Genet 2018.

82. Schreml J, Durmaz B, Cogulu O, Keupp K, Beleggia F, Pohl E, Milz E, Coker M, Ucar SK, Nurnberg G, Nurnberg P, Kuhn J, Ozkinay F. The missing "link": an autosomal recessive short stature syndrome caused by a hypofunctional XYLT1 mutation. Hum Genet. 2014;133(1):29-39.

83. Lopez-Hernandez T, Ridder MC, Montolio M, Capdevila-Nortes X, Polder E, Sirisi S, Duarri A, Schulte U, Fakler B, Nunes V, Scheper GC, Martinez A, Estevez R, van der Knaap MS. Mutant GlialCAM causes megalencephalic leukoencephalopathy with subcortical cysts, benign familial macrocephaly, and macrocephaly with retardation and autism. Am J Hum Genet. 2011; 88(4):422-32.

84. Hamilton EMC, Tekturk P, Cialdella F, van Rappard DF, Wolf NI, Yalcinkaya C, Cetincelik U, Rajaee A, Kariminejad A, Paprocka J, Yapici Z, Bosnjak VM, van der Knaap MS. MLC research group: megalencephalic leukoencephalopathy with subcortical cysts: characterization of disease variants. Neurology. 2018; 90(16):e1395-403.

85. Turkmen S, Guo G, Garshasbi M, Hoffmann K, Alshalah AJ, Mischung C, Kuss A, Humphrey N, Mundlos S, Robinson PN. CA8 mutations cause a novel syndrome characterized by ataxia and mild mental retardation with predisposition to quadrupedal gait. PLoS Genet. 2009;5(5):e1000487.

86. Lam WW, Millichap JJ, Soares DC, Chin R, McLellan A, FitzPatrick DR, Elmslie F, Lees MM, Schaefer GB. DDD study, Abbott CM: novel de novo EEF1A2 missense mutations causing epilepsy and intellectual disability. Mol Genet Genomic Med. 2016;4(4):465-74.

87. Nakajima J, Okamoto N, Tohyama J, Kato M, Arai H, Funahashi O, Tsurusaki Y, Nakashima M, Kawashima H, Saitsu H, Matsumoto N, Miyake N. De novo EEF1A2 mutations in patients with characteristic facial features, intellectual disability, autistic behaviors and epilepsy. Clin Genet. 2015;87(4):356-61.

88. Mackay DS, Bennett TM, Shiels A. Exome sequencing identifies a missense variant in EFEMP1 co-segregating in a family with autosomal dominant primary open-angle glaucoma. PLoS One. 2015;10(7):e0132529.

89. Liu T, Xie L, Ye J, Liu Y, He X. Screening of candidate genes for primary open angle glaucoma. Mol Vis. 2012;18:2119-26.

90. Springelkamp H, Mishra A, Hysi PG, Gharahkhani P, Hohn R, Khor CC, Cooke Bailey JN, Luo X, Ramdas WD, Vithana E, Koh V, Yazar S, Xu L, Forward H, Kearns LS, Amin N, Iglesias Al, Sim KS, van Leeuwen EM, Demirkan A, van der Lee S, Loon SC, Rivadeneira F, Nag A, Sanfilippo PG, Schillert A, de Jong PT, Oostra BA, Uitterlinden AG, Hofman A, NEIGHBORHOOD Consortium, Zhou T, Burdon KP, Spector TD, Lackner KJ, Saw SM, Vingerling JR, Teo YY, Pasquale LR, Wolfs RC, Lemij HG, Tai ES, Jonas JB, Cheng CY, Aung T, Jansonius NM, Klaver CC, Craig JE, Young TL, Haines JL, MacGregor S, Mackey DA, Pfeiffer N, Wong TY, Wiggs JL, Hewitt AW, van Duijn CM, Hammond CJ. Meta-analysis of genome-wide association studies identifies novel loci associated with optic disc morphology. Genet Epidemiol. 2015;39(3):207-16.

91. Cusumano A, Falsini B, Giardina E, Cascella R, Sebastiani J, Marshall J. Doyne honeycomb retinal dystrophy - functional improvement following subthreshold nanopulse laser treatment: a case report. J Med Case Rep. 2019;13(1):5 -018-1935-1.

92. Zhang K, Sun X, Chen Y, Zhong Q, Lin L, Gao Y, Hong F. Doyne honeycomb retinal dystrophy/malattia leventinese induced by EFEMP1 mutation in a Chinese family. BMC Ophthalmol. 2018;18(1):318 -018-0988-7. 
93. Marmorstein LY, Munier FL, Arsenijevic Y, Schorderet DF, McLaughlin PJ, Chung D, Traboulsi E, Marmorstein AD. Aberrant accumulation of EFEMP1 underlies drusen formation in Malattia Leventinese and age-related macular degeneration. Proc Natl Acad Sci U S A. 2002;99(20):13067-72.

94. Hulleman JD, Kelly JW. Genetic ablation of N-linked glycosylation reveals two key folding pathways for R345W fibulin-3, a secreted protein associated with retinal degeneration. FASEB J. 2015;29(2):565-75.

95. Balestri M, Crisafulli C, Donato L, Giegling I, Calati R, Antypa N, Schneider B, Marusic D, Tarozzi ME, Marusic D, Paragi M, Hartmann AM, Konte B, Marsano A, Serretti A, Rujescu D. Nine differentially expressed genes from a post mortem study and their association with suicidal status in a sample of suicide completers, attempters and controls. J Psychiatr Res. 2017;91:98-104.

96. Calati R, Giegling I, Balestri M, Antypa N, Friedl M, Konte B, Hartmann AM, Serretti A, Rujescu D. Influence of differentially expressed genes from suicide post-mortem study on personality traits as endophenotypes on healthy subjects and suicide attempters. Eur Arch Psychiatry Clin Neurosci. 2014;264(5):423-32.

97. Sokolowski M, Wasserman J, Wasserman D. Polygenic associations of neurodevelopmental genes in suicide attempt. Mol Psychiatry. 2016;21(10): 1381-90.

98. Thalmeier A, Dickmann M, Giegling I, Schneider B, Hartmann MA, Maurer K, Schnabel A, Kauert G, Moller HJ, Rujescu D. Gene expression profiling of post-mortem orbitofrontal cortex in violent suicide victims. Int J Neuropsychopharmacol. 2008;11(2):217-28.

99. Antosova B, Smolikova J, Klimova L, Lachova J, Bendova M, Kozmikova I, Machon O, Kozmik Z. The gene regulatory network of lens induction is wired through Meis-dependent shadow enhancers of Pax6. PLoS Genet. 2016;12(12):e1006441.

100. Conte I, Carrella S, Avellino R, Karali M, Marco-Ferreres R, Bovolenta P. Banfi S: miR-204 is required for lens and retinal development via Meis2 targeting. Proc Natl Acad Sci U S A. 2010;107(35):15491-6.

101. Wu CR, Ye M, Qin L, Yin Y, Pei C. Expression of lens-related microRNAs in transparent infant lenses and congenital cataract. Int J Ophthalmol. 2017;10(3):361-5.

102. Heine P, Dohle E, Bumsted-O'Brien K, Engelkamp D, Schulte D. Evidence for an evolutionary conserved role of homothorax/Meis1/2 during vertebrate retina development. Development. 2008;135(5):805-11.

103. Shiga Y, Akiyama M, Nishiguchi KM, Sato K, Shimozawa N, Takahashi A, Momozawa Y, Hirata M, Matsuda K, Yamaji T, Iwasaki M, Tsugane S, Oze I, Mikami H, Naito M, Wakai K, Yoshikawa M, Miyake M, Yamashiro K, Japan Glaucoma Society Omics Group (JGS-OG), Kashiwagi K, Iwata T, Mabuchi F, Takamoto M, Ozaki M, Kawase K, Aihara M, Araie M, Yamamoto T, Kiuchi Y, Nakamura M, Ikeda Y, Sonoda KH, Ishibashi T, Nitta K, Iwase A, Shirato S, Oka Y, Satoh M, Sasaki M, Fuse N, Suzuki Y, Cheng CY, Khor CC, Baskaran M, Perera S, Aung T, Vithana EN, Cooke Bailey JN, Kang JH, Pasquale LR, Haines $J$, NEIGHBORHOOD Consortium, Wiggs JL, Burdon KP, Gharahkhani P, Hewitt AW, Mackey DA, MacGregor S, Craig JE, Allingham RR, Hauser M, Ashaye A, Budenz DL, Akafo S, SEI W, Kamatani Y, Nakazawa T, Kubo M. Genome-wide association study identifies seven novel susceptibility loci for primary open-angle glaucoma. Hum Mol Genet. 2018;27(8):1486-96.

104. Gambin T, Yuan B, Bi W, Liu P, Rosenfeld JA, Coban-Akdemir Z, Pursley AN, SCS N, Marom R, Golla S, Dengle L, Petrie HG, Matalon R, Emrick L, Proud MB, Treadwell-Deering D, Chao HT, Koillinen H, Brown C, Urraca N, Mostafavi R, Bernes S, Roeder ER, Nugent KM, Bader PI, Bellus G, Cummings M, Northrup H, Ashfaq M, Westman R, Wildin R, Beck AE, Immken L, Elton L, Varghese S, Buchanan E, Faivre L, Lefebvre M, Schaaf CP, Walkiewicz M, Yang Y, Kang SL, Lalani SR, Bacino CA, Beaudet AL, Breman AM, Smith JL, Cheung SW, Lupski JR, Patel A, Shaw CA, Stankiewicz P. Identification of novel candidate disease genes from de novo exonic copy number variants. Genome Med. 2017;9(1):83. https://doi.org/10.1186/s13073-017-0472-7.

105. Liu Z, Dai X, Tao W, Liu H, Li H, Yang C, Zhang J, Li X, Chen Y, Ma C, Pei J, Mao H, Chen K, Zhang Z. APOE influences working memory in nondemented elderly through an interaction with SPON1 rs2618516. Hum Brain Mapp. 2018;39(7):2859-67.

106. Senormanci O, Karakas Celik S, Valipour E, Dogan V, Senormanci G. Determination of candidate genes involved in schizophrenia using the whole-exome sequencing. Bratisl Lek Listy. 2018;119(9):572-6.

107. Sherva R, Tripodis Y, Bennett DA, Chibnik LB, Crane PK, de Jager PL, Farrer LA, Saykin AJ, Shulman JM, Naj A, Green RC, GENAROAD Consortium. Alzheimer's disease neuroimaging initiative, Alzheimer's disease genetics consortium: genome-wide association study of the rate of cognitive decline in Alzheimer's disease. Alzheimers Dement. 2014;10(1):45-52.
108. Jahanshad N, Rajagopalan P, Hua X, Hibar DP, Nir TM, Toga AW, Jack CR Jr, Saykin AJ, Green RC, Weiner MW, Medland SE, Montgomery GW, Hansell NK, McMahon KL, de Zubicaray Gl, Martin NG, Wright MJ, Thompson PM. Alzheimer's disease neuroimaging initiative: genome-wide scan of healthy human connectome discovers SPON1 gene variant influencing dementia severity. Proc Natl Acad Sci U S A. 2013;110(12):4768-73.

109. Wolf LV, Yang Y, Wang J, Xie Q, Braunger B, Tamm ER, Zavadil J, Cvekl A. Identification of pax6-dependent gene regulatory networks in the mouse lens. PLoS One. 2009;4(1):e4159.

110. Fernandez-Godino R, Garland DL, Pierce EA. A local complement response by RPE causes early-stage macular degeneration. Hum Mol Genet. 2015; 24(19):5555-69.

111. Protas ME, Weh E, Footz T, Kasberger J, Baraban SC, Levin AV, Katz LJ, Ritch R, Walter MA, Semina EV, Gould DB. Mutations of conserved non-coding elements of PITX2 in patients with ocular dysgenesis and developmental glaucoma. Hum Mol Genet. 2017;26(18):3630-8.

112. Moazzeni H, Mirrahimi M, Moghadam A, Banaei-Esfahani A, Yazdani S, Elahi E: Identification of genes involved in glaucoma pathogenesis using combined network analysis and empirical studies. Hum Mol Genet 2019.

113. Souzeau E, Siggs OM, Zhou T, Galanopoulos A, Hodson T, Taranath D, Mills RA, Landers J, Pater J, Smith JE, Elder JE, Rait JL, Giles P, Phakey V, Staffieri SE, Kearns LS, Dubowsky A, Mackey DA, Hewitt AW, Ruddle JB, Burdon KP, Craig JE. Glaucoma spectrum and age-related prevalence of individuals with FOXC1 and PITX2 variants. Eur J Hum Genet. 2017;25(11):1290.

114. Bockenhauer D, Bokenkamp A, Nuutinen M, Unwin R, Van't Hoff W, Sirimanna T, Vrljicak K, Ludwig M. Novel OCRL mutations in patients with Dent-2 disease. J Pediatr Genet. 2012;1(1):15-23.

115. Montjean R, Aoidi R, Desbois P, Rucci J, Trichet M, Salomon R, Rendu J, -Faure J, Lunardi J, Gacon G, Billuart P, Dorseuil O. OCRL-mutated fibroblasts from patients with Dent-2 disease exhibit INPP5B-independent phenotypic variability relatively to Lowe syndrome cells. Hum Mol Genet. 2015;24(4): 994-1006.

116. Hichri H, Rendu J, Monnier N, Coutton C, Dorseuil O, Poussou RV, Baujat G, Blanchard A, Nobili F, Ranchin B, Remesy M, Salomon R, Satre V, Lunardi J. From Lowe syndrome to Dent disease: correlations between mutations of the OCRL1 gene and clinical and biochemical phenotypes. Hum Mutat. 2011;32(4):379-88

117. Recker F, Zaniew M, Bockenhauer D, Miglietti N, Bokenkamp A, Moczulska A, Rogowska-Kalisz A, Laube G, Said-Conti V, Kasap-Demir B, Niemirska A, Litwin M, Siten G, Chrzanowska KH, Krajewska-Walasek M, Sethi SK, Tasic V, Anglani F, Addis M, Wasilewska A, Szczepanska M, Pawlaczyk K, Sikora P, Ludwig M. Characterization of 28 novel patients expands the mutational and phenotypic spectrum of Lowe syndrome. Pediatr Nephrol. 2015;30(6):931-43.

118. Law CW, Chen Y, Shi W, Smyth GK: Voom: precision weights unlock linear model analysis tools for RNA-seq read counts. Genome Biol 2014, 15(2);doi: https://doi.org/10.1186/gb-2014-15-2-r29.

119. Sanchez-Pulido L, Ponting CP. TMEM132: an ancient architecture of cohesin and immunoglobulin domains define a new family of neural adhesion molecules. Bioinformatics. 2018;34(5):721-4.

120. Chen B, Chou HT, Brautigam CA, Xing W, Yang S, Henry L, Doolittle LK, Walz T, Rosen MK. Rac1 GTPase activates the WAVE regulatory complex through two distinct binding sites. Elife. 2017;6. https://doi.org/10.7554/eLife.29795.

121. Carreras FJ. Lessons from glaucoma: rethinking the fluid-brain barriers in common neurodegenerative disorders. Neural Regen Res. 2019;14(6):962-6.

122. Alqawlaq S, Flanagan JG, Sivak JM: All roads lead to glaucoma: Induced retinal injury cascades contribute to a common neurodegenerative outcome. Exp Eye Res 2018.

123. $\mathrm{Xu} \mathrm{H}$, Chen M. Targeting the complement system for the management of retinal inflammatory and degenerative diseases. Eur J Pharmacol. 2016;787: 94-104.

124. Camaj P, Seeliger H, Ischenko I, Krebs S, Blum H, De Toni EN, Faktorova D, Jauch KW, Bruns CJ. EFEMP1 binds the EGF receptor and activates MAPK and Akt pathways in pancreatic carcinoma cells. Biol Chem. 2009;390(12): 1293-302.

125. Fuchshofer R, Stephan DA, Russell P, Tamm ER. Gene expression profiling of TGFbeta2- and/or BMP7-treated trabecular meshwork3cells: identification of Smad7 as a critical inhibitor of TGF-beta2 signaling. Exp Eye Res. 2009;88(6): 1020-32.

126. Shrestha R, Wen YT, Ding DC, Tsai RK. Aberrant hiPSCs-derived from human keratinocytes differentiates into $3 \mathrm{D}$ retinal organoids that acquire mature photoreceptors. Cells. 2019;8(1). https://doi.org/10.3390/cells8010036. 
127. Zhu W, Jain A, Gramlich OW, Tucker BA, Sheffield VC, Kuehn MH. Restoration of aqueous humor outflow following transplantation of iPSCderived trabecular meshwork cells in a transgenic mouse model of glaucoma. Invest Ophthalmol Vis Sci. 2017;58(4):2054-62.

\section{Publisher's Note}

Springer Nature remains neutral with regard to jurisdictional claims in published maps and institutional affiliations.

Ready to submit your research? Choose BMC and benefit from:

- fast, convenient online submission

- thorough peer review by experienced researchers in your field

- rapid publication on acceptance

- support for research data, including large and complex data types

- gold Open Access which fosters wider collaboration and increased citations

- maximum visibility for your research: over $100 \mathrm{M}$ website views per year

At $B M C$, research is always in progress.

Learn more biomedcentral.com/submissions 